\title{
KEWAJIBAN BANK SYARIAH TERHADAP NASABAH PENYIMPAN DANA AKIBAT INGKAR JANJI MITRA
}

\section{Sisca Ferawati Burhanuddin}

Fakultas Hukum Universitas Pasundan Bandung, Jln. Lengkong Besar No. 68 - Bandung, Telp: 0224262226, Hp: 08122228329, Email: sisca.ferawati@unpas.ac.id.

\begin{abstract}
ABSTRAK
Perbankan Syariah merupakan lembaga keuangan yang menggunakan sistem bagi hasil imbalan. Dalam pembiayaan mudharabah bahwa shahibul maal menginvestasikan modalnya dan mudharib memberikan kemampuan dan reputasinya untuk menjalankan usaha serta berbagi atas hasil usaha tersebut, jika terjadi kerugian shahibul maal akan kehilangan modalnya, dan pihak mudharib akan kehilangan jerih payahnya dalam menjalankan usaha. Pihak bank syariah sebagai perantara para pihak harus bersikap netral, adil, amanah, dan bertanggung jawab dalam hal kerjasama ini.

Metode pendekatan adalah yuridis normatif yaitu penelitian hukum yang menitikberatkan pada penelitian terhadap data sekunder. Untuk memperkuat analisis guna melengkapi data sekunder, dilakukan penelitian lapangan untuk mendapatkan data primer melalui wawancara.

Upaya yang dilakukan apabila ada hubungan hukum 3 pihak yaitu shahibul maal, bank syariah, mudharib mengalami indikasi kerugian tidak sebatas pengawasan tetapi melakukan proses musyawarah mufakat, dan Alternative Dispute Resolution (ADR) untuk mencapai tujuan kerjasama dalam hal penyelamatan dana shahibul maal dan kegiatan usaha mudharib. Pertanggungjawaban Bank Syariah yaitu tanggung jawab normatif artinya dalam hal pemilik dana meminta bank untuk menyalurkan dana mudharabah secara langsung kepada mitra usaha maka, bank bertanggung jawab sebatas kewajiban daripada bank syariah tersebut yaitu dalam pelaksanaan manajemen mitra usaha. Sedangkan tanggung jawab moral harus mengintegrasi nilai-nilai moral dengan tindakan-tindakan ekonomi berdasarkan syariah.
\end{abstract}

Kata Kunci : Tanggung Jawab, Bank, Syariah, Wanprestasi.

Copyright $@$ 2016, LITIGASI, p-ISSN: 0853-7100; e-ISSN: 2442-2274 
Available online at: http://ejournal.unpas.ac.id/index.php/litigasi

Litigasi, Vol. 17(1), 2016, 3075-3132

DOI: http://dx.doi.org/10.23969/litigasi.v17i1.92

\begin{abstract}
Islamic Banking is a financial institution using the system for results in return. In shahibul maal of financing that invest capital and mudharib provide capacity and reputation to run the business and share in the results that, if there is a loss shahibul maal will lose their money, and the party will lose his labor mudharib in running the business. The Islamic banks as intermediaries for the parties should be neutral, fair, trustworthy, and responsible in terms of this cooperation.

Method is a normative juridical approach namely legal research focuses on the study of secondary data. To strengthen in order to complement the analysis of secondary data, conducted field research to obtain primary data through interviews.

Efforts are being made if there is a legal relationship three parties namely shahibul maal, Islamic banks, mudharib have indications of a loss is not limited to oversight, but the process of consensus, and Alternative Dispute Resolution (ADR) to achieve the objectives of cooperation in terms of rescue funds shahibul maal and business activities mudharib , Accountability Islamic Bank is the responsibility of the owner of the normative means in terms of funds requested mudharabah bank to channel funds directly to the business partners, the bank responsible for the extent of liability than the Islamic bank that is in the implementation of business partner management. While the moral responsibility must integrate moral values with economic measures based on sharia.
\end{abstract}

Keywords: Responsibilities, Bank, Sharia, Default.

Copyright @ 2016, LITIGASI, p-ISSN: 0853-7100; e-ISSN: 2442-2274 
Available online at: http://ejournal.unpas.ac.id/index.php/litigasi

Litigasi, Vol. 17(1), 2016, 3075-3132

DOI: http://dx.doi.org/10.23969/litigasi.v17i1.92

\section{PENDAHULUAN}

Di Indonesia ketentuan mengenai bank dengan sistem syariah diatur

Undang-Undang Nomor 21 Tahun 2008 tentang Perbankan Syariah Pasal

1 ayat (1) bahwa pengertian Perbankan Syariah adalah segala sesuatu yang menyangkut tentang Bank Syariah dan Unit Usaha Syariah, mencakup kelembagaan, kegiatan usaha, serta cara dan proses dalam melaksanakan kegiatan usahanya.

Bank Islam atau selanjutnya disebut dengan Bank Syariah adalah bank yang beroperasi dengan tidak mengandalkan pada bunga. Bank syariah atau biasa disebut dengan bank tanpa bunga adalah lembaga keuangan atau perbankan yang operasional atau produknya dikembangkan berlandaskan pada Al-Qur'an an AlHadits Nabi SAW. Dengan kata lain, menurut ketentuan Undang-Undang Nomor 21 Tahun 2008 tentang perbankan syariah Pasal 1 ayat (7) mengenai pengertian dari bank syariah adalah bank yang menjalankan kegiatan usahanya berdasarkan prinsip syariah dan menurut jenisnya terdiri atas Bank Umum Syariah dan Bank Pembiayaan Rakyat Syariah.

Dalam perkembangannya sebagian besar Bank Syariah di Indonesia membagi produknya menjadi 3, yaitu sifatnya penyerapan dana, sifatnya penyaluran dana, dan sifatnya pelayanan jasa-jasa. Produk Bank Syariah yang bersifat penyerapan dana contohnya ialah giro, tabungan, atau deposito yang memakai prinsip wadi'ah atau mudharabah, produk Bank Syariah yang bersifat pembiayaan contohnya ialah pembiayaan dengan prinsip ba'i (jual beli), ijarah (sewa), syirkah (bagi hasil), dan akad pelengkap, dan produk bank syariah yang sifatnya pelayanan jasa-jasa

Copyright @ 2016 , LITIGASI, p-ISSN: 0853-7100; e-ISSN: 2442-2274 
Available online at: http://ejournal.unpas.ac.id/index.php/litigasi

Litigasi, Vol. 17(1), 2016, 3075-3132

DOI: http://dx.doi.org/10.23969/litigasi.v17i1.92

contohnya ialah sharf (jual beli valuta asing) dan ijarah (sewa). (Adiwarman $A$. Karim, 2006 : 97-98).

Penerapan konsep pembiayaan menghimpun dana dalam praktik Perbankan Syariah dilakukan oleh bank dengan menerima dana dari nasabah penyimpan yang dapat berbentuk tabungan atau simpanan deposito dengan jangka waktu yang bervariasi. Kemudian dana yang terkumpul dari nasabah penyimpan ini disalurkan oleh Bank dalam bentuk pembiayaan-pembiayaan yang menghasilkan kepada mitra usahanya. Bank disini dapat berperan ganda selaku pihak dalam akad pembiayaan tersebut yaitu sebagai mudharib atau pengelola dana dari nasabah penyimpannya (shahibul maal / investor), serta sebagai shahibul maal (investor) bagi nasabah peminjam selaku mitra usahanya (mudharib).( Anshori, Abdul Ghofur, 2008 : 99).

Perbankan dengan prinsip syariah sebagai lembaga keuangan alternatif selain bank konvensional bukan berarti tidak mempunyai kelemahan atau mengandung resiko karena setiap usaha pasti menghadapi resiko walaupun kecil. Khususnya praktek perbankan syariah dengan prinsip mudharabah, yaitu penanaman dana (shahibul maal) kepada pengelola dana (mudharib) untuk melakukan kegiatan usaha tertentu, dengan pembagian menggunakan metode bagi untung dan rugi (profit and loss sharing) atau metode bagi pendapatan (revenue sharing) antara kedua belah pihak berdasarkan nisbah yang telah disepakati sebelumnya, berdasarkan Pasal 1 (5) Peraturan Bank Indonesia No. 7/46/PBI/2005 tentang Akad Penghimpunan Dan Penyaluran Dana Bagi Bank Yang Melaksanakan Kegiatan Usaha Berdasarkan Prinsip

Copyright (C) 2016, LITIGASI, p-ISSN: 0853-7100; e-ISSN: 2442-2274 
Syariah. Metode mudharabah dalam perbankan syariah secara teoritis merupakan metode yang rentan terhadap resiko kerugian bagi bank sebagai pemilik dana dibandingkan dengan metode lainnya seperti murabahah, saham, dan lain-lain. Oleh karena itu, upaya yang perlu dilakukan oleh bank syariah untuk mengatasi resiko tersebut adalah dengan kewajiban pengelolaan resiko yang diatur dalam Pasal 38 Undang-Undang Nomor 21 tahun 2008 tentang Perbankan Syariah yang menyebutkan bahwa bank syariah wajib menerapkan manajemen risiko, prinsip mengenal nasabah, dan perlindungan nasabah. Bank syariah wajib menjelaskan kepada nasabah megenai kemungkinan timbulnya resiko kerugian sehubungan dengan transaksi nasabah yang dilakukan melalui bank syariah.

Dalam hal nasabah penerima fasilitas tidak memenuhi kewajibannya maka bank syariah dapat menggunakan lembaga hukum yang berlaku yaitu jaminan. Akan tetapi, jaminan tersebut hanya boleh diambil sebagai pelunasan dana yang telah diberikan oleh bank apabila pihak nasabah benar-benar terbukti menyalahi perjanjian yang mengakibatkan kerugian pengelola dana. (Muhammad, 2001 : 21). Pihak bank tidak boleh mengambil jaminan yang diberikan oleh nasabah, apabila kerugian tersebut bukan karena kecurangan atau kelalaian pihak pengelola dana (Muhammad Syafi'i Antonio, 2001 : 95), sebab di dalam prinsip mudharabah keuntungan dibagi bersama antara pemilik dana selama kerugian itu bukan akibat kelalaian pengelola dana. (ibid). Oleh karena itulah perlu dilakukan upaya-upaya untuk mencegah atau menanggulangi resiko sehingga bank tidak mengalami kerugian-kerugian yang dapat menyebabkan melemahnya kepercayaan terhadap bank syariah.

Copyright @ 2016 , LITIGASI, p-ISSN: 0853-7100; e-ISSN: 2442-2274 
Available online at: http://ejournal.unpas.ac.id/index.php/litigasi

Litigasi, Vol. 17(1), 2016, 3075-3132

DOI: http://dx.doi.org/10.23969/litigasi.v17i1.92

Keuntungan dari penyaluran dana dalam bentuk pembiayaan kepada mitra usahanya (mudharib) akan dibagikan oleh bank kepada nasabah penyimpannya, namun tidak menutup kemungkinan mitra usaha bank (mudharib) mengalami kerugian dalam menjalankan usahanya. Karena dalam dunia bisnis selalu ada kemungkinan rugi, impas atau untung yang besarnya tidak dapat ditentukan dari awal.

Kerugian yang terjadi akibat kegagalan usaha yang dilakukan mitra bank, dengan menggunakan dana pembiayaan yang diberikan pihak bank sebagai investasinya dalam bentuk modal usaha, menjadikan mitra bank tidak melakukan prestasinya sesuai dengan yang diperjanjikan atau dapat dikatakan wanprestasi. Hal ini mengakibatkan bank selaku pemilik modal harus turut menanggung semua resiko atas dana yang telah diinvestasikannya sesuai yang diperjanjikan. Mengingat dana yang dipergunakan oleh pihak bank adalah juga dana dari nasabah penyimpan untuk menjalankan usaha bank, maka tentunya pihak bank syariah harus benar-benar bersikap amanah, dan bertanggung jawab untuk pengelolaan dana tersebut.

Mudharabah merupakan perjanjian pembiayaan berdasarkan prinsip bagi hasil, terdapat kerjasama antara pemilik dana (shahibul maal) dengan pengusaha (mudharib) untuk melakukan usaha bersama. Keuntungan yang diperoleh akan di bagi-bagi dengan perbandingan yang telah disepakati sebelumnya dan kerugian financial akan menjadi tanggungan pemilik atau penyandang dana sedangkan pengelola atau pengusaha tidak memperoleh imbalan atas usaha yang dijalankan. Pada perjanjian mudharabah terbagi menjadi dua jenis yaitu Mudharabah Muthlaqah

Copyright $\odot$ 2016, LITIGASI, p-ISSN: 0853-7100; e-ISSN: 2442-2274 
Available online at: http://ejournal.unpas.ac.id/index.php/litigasi

Litigasi, Vol. 17(1), 2016, 3075-3132

DOI: http://dx.doi.org/10.23969/litigasi.v17i1.92

dan Mudharabah Muqaydah. Mudaharabah muthlaqah, yaitu mudharabah yang tidak memberi batasan atau persyaratan dalam pelaksanaannya. Sedangkan mudharabah muqaydah, yaitu mudharabah yang memberikan batasan atau persyaratan dalam pelaksanaannya dan sekaligus ada tiga pihak yang menjalankan pembiayaan tersebut.

Pada bentuk pertanggungjawaban bank syariah atas dana nasabah tergantung pada akad yang digunakan, apabila digunakan akad mudharabah maka ada yang umum dan khusus. Ketika nasabah menyimpan dananya dengan akad mudharabah muthlaqah atau (bersifat umum), baik dalam bentuk simpanan tabungan maupun deposito yang menggunakan label mudharabah, dimana pihak bank mempergunakan dana nasabah tersebut untuk mengembangkan usahanya dengan melakukan transaksi dengan pihak lain, dimana transaksi tersebut bisa diprediksi dengan relatif pasti tingkat keuntungan dan jangka waktunya, karena telah diperjanjikan terlebih dahulu di awal akad seperti akad jual beli dan sewa menyewa, ataupun jenis usaha lain yang dilakukan bank yang bebas riba dan halal, maka jika terjadi kerugian, pihak shahibul maal (dalam hal ini nasabah penyimpan dana) akan menanggung seluruh resiko yang menyangkut modal yang dikeluarkan untuk menjalankan usaha bank sepanjang tidak ditemukan bukti penyelewengan dan salah urus dalam pengelolaan usaha oleh pihak bank selaku mudharib.

Tetapi ketika nasabah menyimpan dananya dengan akad mudharabah muthlaqah, dan pihak bank mempergunakan dana nasabah tersebut untuk mengembangkan usahanya dengan melakukan transaksi dengan pihak lain

Copyright @ C 2016, LITIGASI, p-ISSN: 0853-7100; e-ISSN: 2442-2274 
Available online at: http://ejournal.unpas.ac.id/index.php/litigasi

Litigasi, Vol. 17(1), 2016, 3075-3132

DOI: http://dx.doi.org/10.23969/litigasi.v17i1.92

menggunakan akad mudharabah sehingga terjadi mudharabah yang kedua yang dilakukan pihak bank dengan mitra usahanya, dimana transaksi tersebut tidak bisa diprediksi dengan pasti besarnya keuntungan, karena sangat bergantung pada hasil investasi disebabkan yang diperjanjikan terlebih dahulu diawal akad bukanlah besarnya keuntungan melainkan nisbah bagi hasil atau prosentase pembagian keuntungan, sedangkan tingkat keuntungan investasinya sendiri bisa positif, nol, atau malah mungkin negatif.

Dalam format pelaksanaan mudharabah seperti ini, secara teori jika terjadi kerugian maka pihak bank harus bertanggungjawab penuh atas resiko kerugian investasi yang dilakukan nasabah penyimpan dana pada bank tersebut karena bank dianggap telah melampaui batas kewenangan yang diberikan nasabah penyimpan. Nasabah penyimpan mempercayakan modalnya untuk dijadikan modal usaha oleh bank, bukan untuk usaha mitra bank.

Sedangkan bentuk pertanggungjawaban bank syariah atas dana nasabah tergantung pada akad yang digunakan, apabila digunakan akad mudharabah yang khusus, dalam hal akad ketika nasabah penyimpan dana meminta pihak bank untuk menyalurkan dananya dengan akad Mudaharabah Muqaydah (on balance sheet) atau yang dikenal dengan deposito investasi khusus, dimana pemilik dana menetapkan syarat-syarat tertentu yang harus dipatuhi pihak bank, misalnya disyaratkan bahwa dana tersebut hanya boleh digunakan untuk bisnis tertentu, atau hanya untuk nasabah tertentu, maka dana ini akan dipisahkan ke dalam suatu pos dana tersendiri yang disebut dan investasi terikat, dimana dana ini akan dikucurkan

Copyright $\odot$ 2016, LITIGASI, p-ISSN: 0853-7100; e-ISSN: 2442-2274 
Available online at: http://ejournal.unpas.ac.id/index.php/litigasi

Litigasi, Vol. 17(1), 2016, 3075-3132

DOI: http://dx.doi.org/10.23969/litigasi.v17i1.92

apabila pihak bank benar-benar telah mendapatkan mitra usaha yang sesuai dengan kriteria yang ditentukan pemilik dana, selain juga telah memenuhi kriteria yang disyaratkan pihak bank.

Dalam format pelaksanaan mudharabah seperti ini pihak bank bertanggung jawab atas sejumlah dana yang diinvestasikan pemilik dana tersebut, hal ini didasari karena pihak bank diberikan kewenangan oleh si pemilik dana untuk mencairkan mitra usaha yang sesuai dengan kriteria yang ditentukan pemilik dana atas dasar pengetahuan, kemampuan, dan pengalaman pihak bank dalam memilih mitra usaha yang ideal dan potensial.

Tetapi ketika nasabah pemilik dananya dengan akad mudharabah muqaydah untuk disalurkan langsung kepada mitra yang telah ditunjuk oleh pemilik dana. Dalam hal pemilik dana meminta menyalurkan dana mudharabah secara langsung kepada mitra usaha, maka bank hanya sebagai perantara yang mempertemukan kedua belah pihak.

Dalam format ini secara teori jika terjadi kerugian maka pemilik dana selaku shahibul maal akan menanggung seluruh resiko yang menyangkut modal yang dikeluarkan untuk menjalankan usaha. Dengan kata lain, dapat dikatakan bahwa bank tidak bertanggungjawab atas resiko kerugian investasi yang dilakukan nasabah penyimpan dana dengan mitra usahanya tersebut, karena nasabah pemilik dana menentukan langsung mitra, dan usahanya yang dipilihnya, dan hanya menugaskan pihak bank menangani masalah pembukuan keuangan.

Copyright @ C 2016, LITIGASI, p-ISSN: 0853-7100; e-ISSN: 2442-2274 
Available online at: http://ejournal.unpas.ac.id/index.php/litigasi

Litigasi, Vol. 17(1), 2016, 3075-3132

DOI: http://dx.doi.org/10.23969/litigasi.v17i1.92

Berdasarkan uraian di atas tampak bahwa dalam perjanjian investasi pembiayaan mudharabah, kepercayaan antara kedua belah pihak sangat dibutuhkan dan merupakan hal terpenting. Shahibul maal tidak memiliki kepercayaan lagi kepada mudharib maka shahibul maal dapat mengakhiri perjanjian mudharabah secara sepihak, dari keterangan tersebut diatas dapatlah dimengerti bahwa tanpa adanya unsur kepercayaan dari pihak shahibul maal kepada pihak mudharib maka perjanjian investasi mudharabah tidak dapat terjadi. Dalam pelaksanaannya akad mudharabah khususnya mudaharabah muqaydah, tidak dapat dihindari kerap kali terjadi masalah-masalah yang berkaitan dengan kelancaran pemenuhan kewajiban pembayaran angsuran pembiayaan oleh pengelola dana (mudharib). Maka pihak investor mengalami kerugian terhadap wanprestasinya mudharib, menyebabkan bukan hanya pihak investor yang bertanggung jawab tetapi pihak bank sebagai pihak ketiga harus pula ikut bertanggung jawab.

Berdasarkan uraian tersebut di atas, maka peneliti mengemukakan permasalahan dalam pembahasan perbankan syariah ini, yaitu pertama adalah bagaimana upaya yang dilakukan bank syariah sebagai penyelamatan dana dalam hal mitra usahanya mengalami indikasi kerugian usaha berdasarkan akad pembiayaan mudharabah. Dan Yang kedua bagaimana pelaksanaan tanggung jawab bank syariah terhadap kerugian nasabah penyimpan dana akibat wanprestasi mitra usahanya dalam akad pembiayaan mudharabah.

Copyright @ C 2016, LITIGASI, p-ISSN: 0853-7100; e-ISSN: 2442-2274 
Available online at: http://ejournal.unpas.ac.id/index.php/litigasi

Litigasi, Vol. 17(1), 2016, 3075-3132

DOI: http://dx.doi.org/10.23969/litigasi.v17i1.92

\section{METODE PENELITIAN}

Metode penelitian yang dipergunakan oleh penulis dalam penelitian ini adalah sebagai berikut :

\section{A. Metode Pendekatan}

Metode pendekatan yang digunakkan dalam penelitian ini adalah Yuridis Normatif yaitu penelitian hukum yang menitikberatkan pada penelitian terhadap data sekunder berupa bahan hukum primer, bahan hukum sekunder dan bahan hukum tersier. Untuk memperkuat analisis guna melengkapi data sekunder, akan dilakukan penelitian lapangan untuk mendapatkan data primer yaitu melalui wawancara.

B. Spesifikasi Penelitian

Spesifikasi penelitian yang dipakai dalam penelitian ini adalah merupakan deskriptif analitis, yaitu penelitian yang bertujuan untuk memberikan gambaran mengenai fakta-fakta disertai analisis yang akurat mengenai teori maupun praktek tanggung jawab bank syariah terhadap kerugian nasabah penyimpan dana akibat wanprestasi mitra usaha. Dalam kajiannya nanti, akan diteliti sejauh mana keterlibatan bank dalam pengelolaan usaha dan tanggung jawab apabila terjadi kerugian dalam usahanya, yang selanjutnya gambaran umum tersebut dianalisis dengan menggunakan teori, perundangan dan pendapat ahli agar diperoleh penyelesaian terbaik atas permasalahan yang diteliti.

Copyright $\odot$ 2016, LITIGASI, p-ISSN: 0853-7100; e-ISSN: 2442-2274 
Available online at: http://ejournal.unpas.ac.id/index.php/litigasi

Litigasi, Vol. 17(1), 2016, 3075-3132

DOI: http://dx.doi.org/10.23969/litigasi.v17i1.92

C. Tahapan Penelitian

Tahapan penelitian dilakukan sebagai berikut :

1. Penelitian kepustakaan (library research)

Penelitian kepustakaan dilakukan dengan mengumpulkan data yang diperoleh dari seluruh literatur, dokumen, hasil penelitian para ahli yang ada kaitannya dengan pokok penelitian ini, data sekunder yang dijadikan sumber utama terdiri dari :

a. Bahan hukum primer yaitu bahan-bahan hukum yang mengikat dan menjadi landasan utama yang dipakai dalam penelitian ini yaitu Perundang-undangan yang berkaitan dengan perbankan, yaitu :

1) Undang-Undang Dasar Negara Republik Indonesia Tahun 1945 Amandemen ke-4.

2) Undang-Undang No. 7 Tahun 1992 tentang Perbankan.

3) Undang-Undang No. 10 Tahun 1998 tentang Perubahan atas UndangUndang No. 7 Tahun 1992 tentang Perbankan.

4) Undang-Undang No. 3 Tahun 2004 tentang perubahan atas UndangUndang No. 23 Tahun 1999 tentang Bank Indonesia.

5) Undang-Undang No. 17 Tahun 2007 Tentang tentang Rencana Pembangunan Jangka Panjang Nasional Tahun 2005-2025.

6) Undang-Undang No. 21 Tahun 2008 tentang Perbankan Syariah. 
Available online at: http://ejournal.unpas.ac.id/index.php/litigasi

Litigasi, Vol. 17(1), 2016, 3075-3132

DOI: http://dx.doi.org/10.23969/litigasi.v17i1.92

7) PBI No.7/46/PBI/2005 tentang Akad Penghimpunan Dan Penyaluran

Dana Bagi Bank Yang Melaksanakan Kegiatan Usaha Berdasarkan Prinsip Syariah.

8) PBI No. 10/16/PBI/2008 tentang Perubahan Atas Peraturan Bank Indonesia No. 9/19/PBI/2007 tentang Pelaksanaan Prinsip Syariah Dalam Kegiatan Penghimpunan Dana Dan Penyaluran Dana Serta Pelayanan Jasa Bank Syariah.

9) Surat Edaran Bank Indonesia No. 10/14/DPbS/Jakarta/17 Maret 2008 tentang Pelakanaan Prinsip Syariah Dalam Kegiatan Penghimpunan Dana Dan Penyaluran Dana Serta Pelayanan Jasa Bank Syariah.

b. Bahan hukum sekunder yaitu bahan pustaka yang berisikan informasi bahan primer yang berupa doktrin (pendapat para ulama dan pendapat para ahli hukum terkemuka), hasil-hasil penelitian, karya ilmiah dari kalangan hukum, serta buku-buku relevan dengan penelitian ini.

c. Bahan hukum tersier / bahan-bahan yang menunjang yaitu bahan yang memberikan petunjuk maupun penjelasan terhadap bahan hukum primer dan sekunder yang berupa kamus, majalah, jurnal-jurnal ilmiah, artikel pada media cetak dan sebagainya.

2. Penelitian lapangan (field research)

Penelitian lapangan yang dimaksud untuk mendapatkan data primer guna mendukung data-data yang berhasil diperoleh dari penelitian kepustakaan

Copyright @ 9 2016, LITIGASI, p-ISSN: 0853-7100; e-ISSN: 2442-2274 
Available online at: http://ejournal.unpas.ac.id/index.php/litigasi

Litigasi, Vol. 17(1), 2016, 3075-3132

DOI: http://dx.doi.org/10.23969/litigasi.v17i1.92

atau untuk mendukung data sekunder maka dilakukan juga penelitian lapangan dengan teknik wawancara dari narasumber sebagai responden.

Penelitian lapangan dilakukan terhadap pihak-pihak yang berkaitan dengan penelitian seperti ke pihak bank syariah, para pakar di bidang Perbankan Syariah, untuk memperoleh bahan hukum yang tidak dijumpai di kepustakaan.

\section{Teknik Pengumpulan Data}

Teknik pengumpulan data dalam penelitan ini dilakukan:

1. Mengumpulkan bahan hukum dengan melakukan studi dokumen / kepustakaan yang dilakukan terhadap bahan hukum sekunder untuk mendapat kajian teoritis.

2. Mengumpulkan bahan hukum dengan melakukan studi lapangan dengan menggunakan bentuk wawancara.

\section{E. Metode Analisis Data}

Untuk menganalisis data dan menarik hasil kesimpulan penelitian, digunakan metode analisis normatif kualitatif. Normatif karena penelitian ini bertolak dari peraturan perundang-undangan yang ada sebagai norma hukum positif. Kualitatif karena data yang dikumpulkan dari penelitian lapangan merupakan analisis data yang berasal informasi-informasi data dan hasil wawancara.

Copyright @ C 2016, LITIGASI, p-ISSN: 0853-7100; e-ISSN: 2442-2274 
Available online at: http://ejournal.unpas.ac.id/index.php/litigasi

Litigasi, Vol. 17(1), 2016, 3075-3132

DOI: http://dx.doi.org/10.23969/litigasi.v17i1.92

\section{F. Lokasi Penelitian}

1. Untuk mendapatkan data primer, penelitian dilakukan di beberapa Kantor Bank Syariah, yaitu Bank Muamalat Indonesia Bandung di Jalan Buah Batu No. 276 A Bandung, Bank Syariah Mandiri Bandung Jalan Ir. H. Djuanda No. 74 Bandung dan Bank Syariah Mandiri Cimahi Jalan Raya Cibabat No. 98 Cimahi.

2. Untuk mendapatkan data sekunder yang berupa bahan hukum primer, bahan hukum sekunder dan bahan hukum tersier, penelitian dilakukan di : perpustakaan Fakultas Hukum UNPAD Bandung, Perpustakaan Pascasarjana UNPAD, Perpustakaan Magister Notariat UNPAD, Perpustakaan UNISBA.

\section{HASIL PENELITIAN DAN ANALISIS}

A. Upaya yang dilakukan bank syariah sebagai penyelamatan dana nasabah dalam hal mitra usahanya mengalami indikasi kerugian usaha berdasarkan pembiayaan mudharabah.

Risiko kerugian atas suatu usaha dalam dunia bisnis adalah sangat mungkin terjadi yang disebabkan bermacam permasalahan. Menyangkut kegiatan usaha yang dimodali oleh pihak bank selaku shahibul maal dengan mitra usahanya selaku mudharib dalam akad mudharabah tentunya juga sangat rentan terhadap risiko kerugian usaha. Kerugian usaha tidaklah mungkin datang secara tiba-tiba melainkan selalu memberikan indikasi penyebab terlebih dahulu.

Copyright $\odot$ 2016, LITIGASI, p-ISSN: 0853-7100; e-ISSN: 2442-2274 
Available online at: http://ejournal.unpas.ac.id/index.php/litigasi

Litigasi, Vol. 17(1), 2016, 3075-3132

DOI: http://dx.doi.org/10.23969/litigasi.v17i1.92

Indikasi kerugian usaha yang dialami mitra usaha salah satunya adalah tidak mampunya memenuhi kewajiban dan tidak lagi kooperatif dengan pihak bank. Hal demikian dari sudut pandang pihak bank dikenal dengan pembiayaan bermasalah, dimana suatu kondisi pembiayaan mengalami penyimpangan dalam pembayaran kembali pembiayaan yang menyebabkan keterlambatan dalam pembiayaan. Faktor penyebab sewaktu pembiayaan bermasalah dari pihak mitra dapat terjadi karena ketidakjujuran mitra, terjadinya mis manajemen usaha. Sedangkan dari pihak bank sendiri faktor penyebab pembiayaan bermasalah adalah karena kurang baiknya pemahaman pihak bank atas bisnis nasabah serta kurang dilakukannya evaluasi atas laporan keuangan yang disajikan, perhitungan modal kerja yang tidak didasarkan pada bisnis nasabah, serta terlalu optimisnya melihat dari aspek sumber pengembaliannya.

Sudut pandang pihak bank terjadinya pembiayaan yang bermasalah ini tentunya akan berakibat tidak baik bagi bank. Di satu sisi bank telah berlaku tidak amanah dan dzalim terhadap nasabah penyimpan dana dengan tidak berhati-hatinya pihak bank dalam menyalurkan kembali dana nasabah penyimpan sehingga bank tidak dapat memberikan bagi hasil yang baik bagi nasabah penyimpan. Disisi lain pihak bank sendiri berakibat kehilangan kesempatan usaha, reputasi bank semakin buruk yang akan berakibat berkurangnya atau berpindahnya nasabah penyimpan dana dan nasabah penyimpan dana yang baru tidak berminat menanamkan dananya. Hal-hal demikian tentunya harus diantisipasi terlebih dahulu oleh pihak bank.

Copyright @ 2016 , LITIGASI, p-ISSN: 0853-7100; e-ISSN: 2442-2274 
Available online at: http://ejournal.unpas.ac.id/index.php/litigasi

Litigasi, Vol. 17(1), 2016, 3075-3132

DOI: http://dx.doi.org/10.23969/litigasi.v17i1.92

Pencegahan terhadap pembiayaan bermasalah oleh pihak bank dilakukan dengan mengetahui dan menguasai aspek bisnis yang akan dijalani mitra, menganalisa pembiayaan sesuai dengan persyaratan, melakukan monitoring fasilitas pembiayaan dengan baik, menerapkan manajemen penggolongan tingkat kelancaran pembayaran kewajiban mitra sehingga pihak bank dapat secara cepat mengetahui langkah-langkah yang harus dilakukan sehingga tingkat kesehatan pembiayaan selalu stabil yang akhirnya memberikan kontribusi positif. Dalam hal terjadi indikasi kerugian oleh mitra usaha bank dalam akad mudharabah yang akan menyebabkan pembiayaan tersebut menjadi bermasalah, pihak bank harus selalu memperhatikan gejala dini dari pembiayaan bermasalah, untuk segera melakukan penyelamatan dana pembiayaan.

Dalam hal pembiayaan dikaitkan dengan Peraturan Bank Indonesia No.10/16/PBI/2008 tentang Perubahan Atas PBI No.9/19/PBI/2007 tentang Pelaksanaan Prinsip Syariah Dalam Kegiatan Penghimpunan Dana dan Penyaluran Dana Serta Pelayanan Jasa Bank Syariah Pasal 3 huruf b dan c yang menyatakan bahwa dalam kegiatan penyaluran dana berupa pembiayaan dengan mempergunakan antara lain Akad Mudharabah, Musyarakah, Murabahah, Salam, Istishna, Ijarah, Ijarah Muntahiya Bitamlik dan Qardh, dan dalam kegiatan pelayanan jasa dengan mempergunakan antara lain Akad Kafalah, Hawalah dan Sharf. Pembiayaan tersebut yang dilakukan bank menyebabkan terjadi permasalahan yang berpotensi menimbulkan kerugian oleh mitranya, maka bank secara cepat harus mengambil langkah untuk penyelamatan dana

Copyright @ 2016 , LITIGASI, p-ISSN: 0853-7100; e-ISSN: 2442-2274 
Available online at: http://ejournal.unpas.ac.id/index.php/litigasi

Litigasi, Vol. 17(1), 2016, 3075-3132

DOI: http://dx.doi.org/10.23969/litigasi.v17i1.92

dalam hal terjadi indikasi kerugian usaha, mengingat dana yang dipergunakan merupakan dana nasabah penyimpan yang dipercayakan kepada bank dalam pengelolaannya. Adapun langkah-langkah penanganan yang ditempuh pihak bank sebagai langkah penyelamatan dana dalam hal mitra usaha mengalami indikasi kerugian adalah dengan jalan musyawarah untuk mufakat melalui proses revitalisasi (penyehatan pembiayaan).

Dari hasil penelitian didapatkan data-data primer dan sekunder, bahwa proses revitalisasi atau penyehatan pembiayaan bermasalah ini hanya dilakukan kepada mitra usaha (mudharib) bank yang telah atau diperkirakan akan mengalami kesulitan pembayaran kewajiban kepada bank syariah, dimana mitra usaha memiliki kemauan untuk melakukan upaya penyehatan serta itikad baik untuk memenuhi kewajibannya. Ketertundaan pemenuhan kewajiban oleh mitra usaha, bukanlah disebabkan karena kesengajaannya. Selain itu berdasarkan hasil evaluasi ulang pembiayaan yang dilakukan, terdapat indikasi bahwa usaha mitra masih berjalan dan memiliki prospek usaha yang baik serta hasil usaha nasabah diyakini masih mampu untuk memenuhi kewajibannya kepada bank.

Proses penyehatan yang dilakukan bank syariah tersebut mengacu pada Bank Indonesia melalui Surat Keputusan Direksi No 30/51/KEP/DIR tanggal 12 November Tahun 1998 Tentang Restrukturisasi Kredit, menyatakan bahwa bank menganggap perlu untuk melakukan restrukturisasi, bank dapat melakukan beberapa cara sebagai berikut :

Copyright @ 2016 , LITIGASI, p-ISSN: 0853-7100; e-ISSN: 2442-2274 
Available online at: http://ejournal.unpas.ac.id/index.php/litigasi

Litigasi, Vol. 17(1), 2016, 3075-3132

DOI: http://dx.doi.org/10.23969/litigasi.v17i1.92

a. Melakukan pengurangan tunggakan kewajibannya;

b. Melakukan perpanjangan akadnya;

c. Melakukan penambahan fasilitasnya;

d. Melakukan pengambilalihan aset nasabah untuk pelunasan;

e. Melakukan konversi menjadi penyertaan modal.

Untuk mengurangi kemungkinan terjadinya risiko-risiko, maka bank syariah dapat menerapkan sejumlah batasan-batasan tertentu ketika menyalurkan pembiayaan kepada mudharib. Batasan-batasan ini dikenal sebagai incentivecompatible constraints. Melalui incentive-compatible constraints ini, mudharib secara sistematis "dipaksa" untuk berperilaku memaksimalkan keuntungan bagi kedua belah pihak, baik bagi mudharib itu sendiri maupun bagi shahibul maal.

Pada dasarnya, ada empat panduan umum bagi incentive-compatible constraints, yakni :

1. Menetapkan kovenan (syarat) agar porsi modal dari pihak mudharib-nya lebih besar dan/atau mengenakan jaminan (higher stake in net worth and/or collateral).

2. Menetapkan kovenan (syarat) agar mudharib melakukan bisnis yang risiko operasinya lebih rendah (lower operating risk).

3. Menetapkan kovenan (syarat) agar mudharib melakukan bisnis dengan arus kas yang transparan (lower fraction of unobservable cash flow).

4. Menetapkan kovenan (syarat) agar mudharib melakukan bisnis yang biaya tidak terkontrolnya rendah (lower fraction of non-controllable costs).

Copyright @ 2016, LITIGASI, p-ISSN: 0853-7100; e-ISSN: 2442-2274 
Available online at: http://ejournal.unpas.ac.id/index.php/litigasi

Litigasi, Vol. 17(1), 2016, 3075-3132

DOI: http://dx.doi.org/10.23969/litigasi.v17i1.92

Selain itu prinsip kehati-hatian yang ditetapkan oleh Bank Indonesia tercantum dalam Peraturan Bank Indonesia Nomor 3/10/PBI/2001 tentang Penerapan Prinsip Mengenal Nasabah, yang kemudian diubah dengan Peraturan Bank Indonesia Nomor 3/23/PBI/2001. Adapun hal-hal yang dituangkan dalam PBI ini antara lain yaitu :

1) Bank wajib menetapkan kebijakan penerimaan nasabah;

2) Bank wajib menetapkan prosedur dalam mengidentifikasi nasabah;

3) Bank wajib menetapkan kebijakan dan prosedur pemantauan terhadap rekening dan transaksi nasabah;

4) Bank wajib menetapkan kebijakan dan prosedur manajemen risiko yang berkaitan dengan penerapan prinsip mengenal nasabah;

5) Sebelum melakukan hubungan usaha dengan nasabah, bank wajib meminta informasi mengenai :

a. Identitas calon nasabah;

b. Maksud dan tujuan hubungan usaha yang akan dilakukan calon nasabah dengan bank;

c. Informasi lain yang memungkinkan bank untuk dapat mengetahui profil calon nasabah; dan

d. Identitas pihak lain, dalam hal calon nasabah bertindak untuk dan atas nama pihak lain.

Copyright @ C 2016, LITIGASI, p-ISSN: 0853-7100; e-ISSN: 2442-2274 
Available online at: http://ejournal.unpas.ac.id/index.php/litigasi

Litigasi, Vol. 17(1), 2016, 3075-3132

DOI: http://dx.doi.org/10.23969/litigasi.v17i1.92

6) Identitas dari calon nasabah tersebut harus dibuktikan dengan dokumendokumen pendukung, yang sebenarnya harus diteliti terlebih dahulu oleh pihak bank.

Dapat dilihat dalam Undang-Undang Nomor 21 Tahun 2008 tentang Perbankan Syariah Pasal 35 (1) yang menyatakan bahwa Bank Syariah dan Unit Usaha Syariah dalam melakukan kegiatan usahanya wajib menerapkan prinsipkehati-hatian. Hal ini perlu dalam rangka menjamin terlaksananya pengambilan keputusan dalam pengelolaan bank sesuai dengan prinsip kehati-hatian, Bank memiliki dan menerapkan antara lain sistem pengawasan intern. Pasal 38 (1), yang menyatakan bahwa Bank Syariah dan Unit Usaha Syariah wajib menerapkan manajemen risiko, prinsip mengenal nasabah, dan perlindungan nasabah. Dari kegiatan usaha bank dilakukan serangkaian prosedur dan metodologi yang digunakan oleh perbankan untuk mengidentifikasi, mengukur, memantau, dan mengendalikan risiko yang timbul dari kegiatan usaha tersebut. Prinsip yang diterapkan oleh perbankan mengenai prinsip mengenal nasabah yang mencakup kegiatan penerimaan dan identifikasi nasabah serta pemantauan kegiatan transaksi nasabah, termasuk pelaporan transaksi yang mencurigakan. Sedangkan perlindungan nasabah dilakukan antara lain dengan cara adanya mekanisme pengaduan nasabah, meningkatkan transparansi produk, dan edukasi terhadap nasabah.

Berdasarkan peraturan tersebut maka Bank Muamalat Indonesia menetapkan bentuk prinsip kehati-hatian yang dijalankannya dalam pemberian

Copyright $\odot$ 2016, LITIGASI, p-ISSN: 0853-7100; e-ISSN: 2442-2274 
Available online at: http://ejournal.unpas.ac.id/index.php/litigasi

Litigasi, Vol. 17(1), 2016, 3075-3132

DOI: http://dx.doi.org/10.23969/litigasi.v17i1.92

pembiayaan mudharabah melalui ketentuan yang dijalankannya dalam pemberian pembiayaan mudharabah adalah melalui 2 (dua) cara yaitu pengawasan preventif dan pengawasan represif.

1. Pengawasan Preventif

Pengawasan preventif merupakan pengawasan yang dilakukan pihak bank sebelumnya adanya persetujuan pemberian pembiayaan kepada calon nasabah dilaksanakan sebagai wujud dari keyakinan pihak bank atas calon nasabah. Pengawasan preventif yang dilakukan oleh pihak Bank Muamalat Indonesia terdiri dari :

a. Pemeriksaan awal dengan memperhatikan prinsip $5 \mathrm{C}$

Analisis yang mendalam ini dijabarkan lebih lanjut dalam pelaksanaannya dengan melakukan analisa terhadap prinsip 5C sebagai langkah awal dalam melakukan pengenalan terhadap calon nasabah, yaitu :

1) Character atau watak (calon) nasabah.

Dilihat dari kejujurannya lewat investigasi yang dilakukan oleh maker, kebiasaan (calon) nasabah dalam perbankan syariah sebagai seorang muslim yang mempunyai kewajiban terhadap Allah SWT yaitu dengan melakukan ibadah 5 waktu berupa shalat, keadaan lingkungan keluarga (calon) nasabah dan riwayat peminjaman yang telah lalu (apabila calon nasabah sebelumnya pernah mengajukan pembiayaan/kredit pada bank lain). Unsur

Copyright @ C 2016, LITIGASI, p-ISSN: 0853-7100; e-ISSN: 2442-2274 
Available online at: http://ejournal.unpas.ac.id/index.php/litigasi

Litigasi, Vol. 17(1), 2016, 3075-3132

DOI: http://dx.doi.org/10.23969/litigasi.v17i1.92

kemauan dari (calon) nasabah untuk melunasi pembiayaan mudharabah tersebut merupakan hal yang tidak boleh terlupakan.

Selain itu hal yang terpenting yang harus diperhatikan adalah adanya manajemen risiko mengenai pengenalan (calon) nasabah yang mempunyai reputasi baik, misalnya seorang Pimpinan Majelis mempunyai reputasi bahwa ia pernah melakukan perselingkuhan dari istrinya. Maka ia mempunyai reputasi yang tidak baik, dan tidak pantas menjadi panutan yang menyebabkan keraguan apabila menjadi (calon) nasabah dalam perbankan syariah.

2) Capital atau modal (calon) nasabah.

Dalam modal ini yang dilihat adalah jumlah dana yang dimiliki nasabah untuk membeli barang yang diperlukannya. Dengan kata lain, (calon) nasabah dalam mengajukan permohonan pembiayaan pun harus memiliki setidaknya uang muka untuk membuka rekening yang akan digunakan sebagai cara pelunasan pembiayaan nantinya. Selain itu (calon) nasabah harus memberikan keyakinan kepada pihak bank mengenai modal yang digunakan adalah bersumber dari kegiatan yang halal.

3) Capacity atau kemampuan (calon) nasabah.

Kemampuan (calon) nasabah untuk melunasi pembiayaan mudharabah, dilihat dari usaha (calon) nasabah yang menjadi sumber pelunasan pembiayaan mudharabah. Dalam pembiayaan 
Available online at: http://ejournal.unpas.ac.id/index.php/litigasi

Litigasi, Vol. 17(1), 2016, 3075-3132

DOI: http://dx.doi.org/10.23969/litigasi.v17i1.92

mudharabah untuk tujuan konsumtif, hal ini bisa diprediksi secara jelas, tetapi untuk pembiayaan mudharabah dengan tujuan produktif pihak bank harus benar-benar selektif dalam melakukan penilaian. Di sini pihak bank harus benar-benar memperhitungkan aspek-aspek yang ada antara lain, aspek hukum, aspek pemasaran, aspek keuangan, aspek manajemen, aspek amdal.

4) Condition of Economic atau kondisi ekonomi (calon) nasabah.

Melihat faktor-faktor luar (ekonomi makro) yang mungkin terjadi dapat mempengaruhi kegiatan usaha (calon) nasabah yang menjadi sumber pelunasan dari pembiayaan nasabah.

5) Collateral atau agunan (calon) nasabah.

Bank Muamalat Indonesia juga menerapkan untuk adanya agunan, seperti halnya bank konvensional. Nilai dari agunan itu sendiri harus dapat menutupi jumlah dari pembiayaan yang dimohon oleh (calon) nasabah.

b. Adanya penetapan jangka waktu maksimal di dalam pembiayaan mudharabah.

Penetapan jangka waktu di sini dengan mempertimbangkan, tingkat margin keuntungan dan prediksi perubahannya di masa mendatang, perkiraan bagi hasil kepada dana pihak ketiga yang kompetitif di pasar perbankan syariah.

Copyright @ C 2016, LITIGASI, p-ISSN: 0853-7100; e-ISSN: 2442-2274 
Available online at: http://ejournal.unpas.ac.id/index.php/litigasi

Litigasi, Vol. 17(1), 2016, 3075-3132

DOI: http://dx.doi.org/10.23969/litigasi.v17i1.92

2. Pengawasan Represif

Pengawasan represif biasanya dilakukan oleh pihak bank dalam hal nasabah mengajukan permohonan pembiayaan mudharabah dengan tujuan produktif, untuk pembiayaan dengan tujuan konsumtif biasanya tidak dilakukan pengawasan, kecuali pembiayaan yang diberikan kepada nasabah mulai bermasalah. Pihak bank melakukan pengawasan untuk mengetahui perkembangan usaha nasabah untuk dijadikan penilaian apakah pembiayaan tersebut akan bermasalah atau tidak. Pengawasan biasanya dilakukan 3 bulan sekali dimana marketing lending melakukan pengecekan langsung ke lapangan, untuk melihat kondisi usaha nasabah. Namun setiap sebulan sekali nasabah juga diwajibkan untuk menyerahkan laporan keuangan usahanya.

Selain melalui analisis 5C di atas, tindakan hati-hati Bank Muamalat Indonesia untuk meminimalisir kerugiannya yaitu dengan mengambil 7 langkah, yaitu :

1. Tentang penggolongan peminjam (party)

Bank perlu melakukan penggolongan calon debitur berdasarkan watak, kemampuan, dan modal. Hal ini untuk memberikan arah bagi analisis bank untuk bersikap dalam pemberian kredit.

2. Tentang tujuan (purpose)

Pemberian kredit bank terhadap calon debitur patut untuk dipertimbangkan dari dampak positifnya dari sisi ekonomi dan sosial.

Copyright @ C 2016, LITIGASI, p-ISSN: 0853-7100; e-ISSN: 2442-2274 
Available online at: http://ejournal.unpas.ac.id/index.php/litigasi

Litigasi, Vol. 17(1), 2016, 3075-3132

DOI: http://dx.doi.org/10.23969/litigasi.v17i1.92

3. Tentang sumber pembayaran (payment)

Analisis kredit setelah mempertimbangkan tentang dampak positif, ekonomi dan sosial, kemudian harus diprediksi pendapatan yang akan diperoleh calon debitur dari hasil penggunaan kredit. Pendapatan calon debitur harus cukup untuk pengembalian pokok kredit (sekaligus atau diangsur dan nisbah serta biaya-biaya lainnya).

4. Tentang kemampuan memperoleh laba (profitability)

Merupakan kemampuan calon debitur untuk memperoleh keuntungan dari usahanya. Kemampuan ini diukur dari jumlah kewajiban, baik angsuran, nisbah, dan biaya-biaya kredit yang harus dibayar calon debitur. Bila diperkirakan mampu untuk mengatasinya, maka calon debitur dipandang memiliki kemampuan memperoleh keuntungan.

5. Tentang perlindungan (protection)

Analis kredit perlu memperhatikan agunan yang diberikan calon debitur, yang dinilai bukan saja nilai pasar dari agunan yang diserahkan tapi dipertimbangkan dulu perbuatan yang telah dilakukan terhadap agunan, misalnya telah diikat dengan hak tanggungan.

6. Personality

Yaitu menilai nasabah dari segi kepribadiannya atau tingkah lakunya seharihari maupun masa lalunya salah satunya mengenai pelaksanaan ibadah wajib 5 waktu, yang mencakup sikap salah satunya sikap pimpinan agama yang

Copyright @ C 2016, LITIGASI, p-ISSN: 0853-7100; e-ISSN: 2442-2274 
Available online at: http://ejournal.unpas.ac.id/index.php/litigasi

Litigasi, Vol. 17(1), 2016, 3075-3132

DOI: http://dx.doi.org/10.23969/litigasi.v17i1.92

harus mempunyai reputasi yang baik, emosi, tingkah laku dan tindakan nasabah dalam menghadapi risiko.

7. Prospect

Yaitu menilai usaha nasabah di masa yang akan datang menguntungkan atau tidak dengan kata lain kemampuan nasabah dalam menghadapi risiko.

Selain bank syariah, upaya untuk mencegah dan menanggulangi kerugian hendaknya juga dilakukan oleh nasabah mudharib. Upaya yang dilakukan antara lain tidak menjalankan usaha yang tinggi risiko kerugiannya serta mengasuransikan usahanya pada perusahaan asuransi yang menjalankan usahanya berdasarkan prinsip syariah.

Dari data sekunder yang didapatkan melalui penelitian lapangan pada bank syariah didapatkan data bahwa proses penyehatan pembiayaan bermasalah atau revitalisasi umumnya bank syariah cenderung untuk menempuh langkah penyehatan yang meliputi hal-hal berikut, yaitu :

1. Penjadwalan kembali (Rescheduling);

Perubahan ketentuan yang hanya menyangkut jadwal pembayaran atau jangka waktunya. Usaha penyelamatan dana untuk pembiayaan dilakukan dengan merubah jangka waktu pembayaran sehingga memperpanjang jangka waktu kontrak kerja sama agar usaha yang dilaksanakan dapat berkembang dengan lebih leluasa untuk dapat memberikan hasil sesuai dengan yang direncanakan.

Copyright @ C 2016, LITIGASI, p-ISSN: 0853-7100; e-ISSN: 2442-2274 
Available online at: http://ejournal.unpas.ac.id/index.php/litigasi

Litigasi, Vol. 17(1), 2016, 3075-3132

DOI: http://dx.doi.org/10.23969/litigasi.v17i1.92

2. Penataan kembali (Restructuring)

Perubahan sebagian atau seluruh ketentuan pembiayaan termasuk perubahan maksimum saldo pembiayaan. Usaha penyelamatan dana untuk pembiayaan tersebut dilakukan dengan penyesuaian kemampuan keuangan nasabah. Realisasinya dapat berupa penambahan modal atau perhitungan kembali bagi hasil yang direncanakan.

3. Perubahan persyaratan (Reconditioning)

Perubahan sebagian atau seluruhnya ketentuan pembiayaan termasuk perubahan jangka waktu dan persyaratan lainnya sepanjang tidak menyangkut perubahan maksimum saldo pembiayaan.

4. Bantuan manajemen

Penyehatan pembiayaan melalui penempatan sumber daya insani pada posisi manajemen oleh bank. Usaha penyelamatan dana ini dilakukan bila permasalahan yang terjadi adalah karena kesalahan manajemen, serta sumber pengembalian pembiayaan masih potensial.

Sedangkan pembiayaan mudharabah dalam kasus peneliti hubungan hukumnya tiga pihak jadi berbeda, proses-proses yang ditawarkan tidak sebatas pengawasan seperti dijelaskan di atas tetapi dengan jalan dengan jalan musyawarah untuk mufakat dan Alternative Dispute Resolution (ADR) yang dilakukan pihak bank dalam rangka penyehatan atas pembiayaan yang diberikannya, hanya diperuntukkan kepada mitra usaha yang masih memiliki prospek usaha yang baik. Menurut peneliti proses penyehatan pembiayaan yang

Copyright @ 9 2016, LITIGASI, p-ISSN: 0853-7100; e-ISSN: 2442-2274 
Available online at: http://ejournal.unpas.ac.id/index.php/litigasi

Litigasi, Vol. 17(1), 2016, 3075-3132

DOI: http://dx.doi.org/10.23969/litigasi.v17i1.92

akan dilakukan jangan sampai pihak bank syariah memberikan bantuan manajemen dengan menempatkan pihaknya pada posisi manajemen mitra usaha, karena hal tersebut bertentangan dengan konsep mudharabah itu sendiri yang melarang pihak pemodal mencampuri usaha mitra. Untuk usaha yang sudah tidak berjalan atau tidak dapat diharapkan (kinerja mudharib), upaya yang dilakukan pihak bank adalah memperoleh kembali sejumlah dana yang telah dikeluarkan untuk pembiayaan modal usaha yang bermasalah tersebut.

Setiap terjadinya pembiayaan yang macet pihak Bank Muamalat Indonesia Cabang Bandung tetap mengupayakan penyelesaian dengan jalan kekeluargaan. Pihak bank tidak menutup kemungkinan untuk apabila ada kerabat nasabah yang bersedia menjamin dan melunasi utang nasabah tersebut.

Dalam Islam sangat dianjurkan untuk menyelesaikan masalah dengan jalan damai, yaitu melalui suatu musyawarah, seperti tercantum dalam Surat Ali 'Imran ayat 159 dan Asy Syuura ayat 38 yang artinya yaitu : " ....dan bermusyawarahlah dengan mereka dalam urusan itu..."

(Departemen Agama Republik Indonesia, 2002:133).

“...sedang urusan mereka diputuskan dengan musyawarah antara mereka..." Departemen Agama Republik Indonesia, 2002:819).

Sehingga untuk lebih mencerminkan prinsip syariah, dalam hal terjadinya suatu pembiayaan yang bermasalah, pihak bank mengusahakan untuk dapat menyelesaikan dengan jalan musyawarah secara kekeluargaan. Hingga saat

Copyright @ 2016 , LITIGASI, p-ISSN: 0853-7100; e-ISSN: 2442-2274 
Available online at: http://ejournal.unpas.ac.id/index.php/litigasi

Litigasi, Vol. 17(1), 2016, 3075-3132

DOI: http://dx.doi.org/10.23969/litigasi.v17i1.92

ini penyelesaian permasalahan di Bank Muamalat Indonesia Cabang Bandung cukup dengan jalan musyawarah tidak sampai pada tahap litigasi.

Penyelesaian pembiayaan bermasalah atas pemberian modal usaha kepada mitra yang mengalami kerugian yang disebabkan oleh perilaku buruk mitra usaha akan diselesaikan melalui jaminan. Penyelesaian melalui jaminan ini dilakukan bila berdasarkan hasil evaluasi ulang pembiayaan, nasabah tidak memiliki usaha dan tidak lagi kooperatif untuk menyelesaikan pembiayaan. Penyelesaian melalui jaminan ini juga dilakukan jika revitalisasi proses tidak dilakukan. Upaya penyelesaian pembiayaan dilakukan melalui penyerahan jaminan serta sukarela oleh mitra usaha kepada bank agar jaminan yang diberikannya dapat dijual kepada pihak lain ataupun kepada pihak bank syariah itu sendiri untuk menyelesaikan pembiayaan yang bermasalah.

Jika pihak bank ingin membeli benda jaminan untuk membentuk penyelesaian pembiayaan maka langkah yang harus diperhatikan pihak bank adalah bank harus melakukan analisa nilai jaminan untuk menutup seluruh kewajiban dan biaya-biaya untuk proses penyelesaian, melakukan negosiasi dengan nasabah untuk pembelian jaminan, bila nasabah ingin membeli kembali jaminan yang akan dibeli oleh bank, maka pemberian hak pilih dengan jangka waktu berdasarkan persetujuan kedua belah pihak, melakukan pengikatan jual beli setelah terlebih dahulu mendapat persetujuan komite penyelesaian pembiayaan, untuk akhirnya melakukan proses pelunasan pembiayaan dan proses pengadministrasian lainnya.

Copyright (C) 2016, LITIGASI, p-ISSN: 0853-7100; e-ISSN: 2442-2274 
Available online at: http://ejournal.unpas.ac.id/index.php/litigasi

Litigasi, Vol. 17(1), 2016, 3075-3132

DOI: http://dx.doi.org/10.23969/litigasi.v17i1.92

Langkah penyelesaian pembiayaan melalui jaminan lainnya adalah dengan riil eksekusi jaminan. Riil eksekusi jaminan dilakukan apabila jaminan yang telah ada diikat dengan hak tanggungan sehingga bank memiliki hak preference terhadap pelunasan pembiayaan yang bersumber dari jaminan, yang dengan meminta pengadilan negeri untuk melaksanakan eksekusi atas jaminan yang ada berdasarkan sertifikat hak tanggungan yang memuat irah-irah "Demi Keadilan Berdasarkan Ketuhanan Yang Maha Esa" yang mempunyai kekuatan hukum yang tetap dan pasti yang dipersamakan dengan keputusan hakim sehingga dapat dimintakan pelaksanaan eksekusinya.

Pelaksanaan eksekusi diawali dengan teguran/peringatan kepada mitra agar segera memenuhi kewajibannya kepada bank, dalam tahapan ini apabila mitra bersedia memenuhi kewajibannya kepada bank dengan pembayaran tunai ataupun jual jaminan secara sukarela dimana hasil dari penjualan tersebut digunakan untuk melunasi kewajiban sebagai pelaksanaan Pasal 6 UndangUndang Hak Tanggungan maka permohonan eksekusi dapat dicabut oleh pihak bank. Apabila pihak mitra tidak bersedia memenuhi kewajibannya, maka dilakukan proses selanjutnya yaitu dengan sita eksekusi yang dilakukan oleh juru sita pengadilan.

Dalam permasalahan yang diteliti adalah akad mudharabah muqaydah hubungan hukum antara para pihak berbeda dengan bank konvensional karena pihaknya ada tiga yaitu, Nasabah, Bank, dan Mitra Usaha. Bank di sini harus aktif, bukan hanya sebagai pengawas karena bank berada pada posisi perantara

Copyright @ 2016 , LITIGASI, p-ISSN: 0853-7100; e-ISSN: 2442-2274 
Available online at: http://ejournal.unpas.ac.id/index.php/litigasi

Litigasi, Vol. 17(1), 2016, 3075-3132

DOI: http://dx.doi.org/10.23969/litigasi.v17i1.92

yang mempertemukan antara pemilik dana dengan mitra usaha yang akan menjalankan usaha. Pihak bank syariah melakukan upayanya lebih luas karena melakukan kerjasama antara pihak nasabah dan mitra usaha, berdasarkan syariah bank mendapatkan pendapatan di luar kredit (arranger fee).

Di samping model penyelesaian sengketa secara konvensional seperti yang dijelaskan di atas, sedangkan upaya yang dilakukan bank syariah sebagai penyelamatan dana dalam hal mitra usahanya mengalami indikasi kerugian usaha menggunakan musyawarah mufakat pada umumnya dengan cara Alternative Dispute Resolution (ADR). ADR sebagai salah satu cara untuk menyelesaikan sengketa sudah semenjak lama dikenal dalam berbagai kepercayaan dan kebudayaan. Bagi Indonesia, dengan diberlakukannya Undang-Undang No. 30 Tahun 1999 tentang Arbitrase dan Alternatif Penyelesaian Sengketa umum memang dibutuhkan. Hal ini diperlukan sebelum masyarakat khususnya para praktisi hukum menjadi masyarakat yang "litigous minded", apalagi konsep penyelesaian ini sebenarnya sudah berakar dalam kebudayaan kita. Keberadaan ADR penting dalam rangka mengantisipasi globalisasi dimana sistem hukum akan menjadi tidak berbatas sehingga perlu penyelesaian sengketa yang sistemnya dapat diterima oleh semua pihak dengan berbagai latar belakang (Susanti Adi Nugroho, $2009: 5$ ).

Pasal 6 Undang-Undang No. 30 Tahun 1999 telah menyediakan beberapa pranata pilihan penyelesaian sengketa secara damai yang dapat ditempuh para pihak untuk menyelesaikan sengketa atau beda pendapat mereka,

Copyright $\odot$ 2016, LITIGASI, p-ISSN: 0853-7100; e-ISSN: 2442-2274 
Available online at: http://ejournal.unpas.ac.id/index.php/litigasi

Litigasi, Vol. 17(1), 2016, 3075-3132

DOI: http://dx.doi.org/10.23969/litigasi.v17i1.92

apakah dengan mendayagunakan pranata adjudikasi, konsultasi, negosiasi, mediasi, konsiliasi atau penialaian ahli. Tujuan penyelesaian dalam bentuk perdamaian ini hanya bisa tercapai bila didasarkan itikad baik, dan tekat untuk menyampingkan pilihan penyelesaian litigasi melalui pengadilan (Susanti Adi Nugroho, $2009: 5$ ).

Masyarakat bisnis utamanya menginginkan adanya penyelesaian sengketa yang sederhana, cepat dan murah serta tepat. Penyelesaian sengketa yang lambat akan dapat mengganggu kinerja pebisnis dalam menggerakan roda perekonomian serta memerlukan biaya yang relatif besar.

Negosiasi adalah proses konsensus yang digunakan para pihak untuk memperoleh kesepakatan di antara mereka. Negosiasi adalah komunikasi dua arah yang dirancang untuk mencapai kesepakatan pada saat kedua belah pihak memiliki berbagai kepentingan yang sama maupun berbeda. Negosiasi dilakukan apabila komunikasi antar pihak yang bersengketa masih terjalin dengan masih ada rasa saling percaya, dan ada keinginan untuk cepat mendapatkan kesepakatan dan meneruskan hubungan baik (Suyud Margono, 2004 : 28).

Secara sederhana negosiasi berarti suatu proses tawar menawar atau upaya untuk mencapai kesepakatan dengan pihak lain melalui proses interaksi, komunikasi yang dinamis dengan tujuan untuk mendapatkan penyelesaian atau jalan keluar atas suatu masalah yang sedang berlangsung. Inti dari negosiasi dengan tujuan untuk menyelesaikan permasalahan yang timbul dilakukan kedua belah pihak yang bermasalah, bukan dengan bantuan pihak ketiga seperti

Copyright $\odot$ 2016, LITIGASI, p-ISSN: 0853-7100; e-ISSN: 2442-2274 
Available online at: http://ejournal.unpas.ac.id/index.php/litigasi

Litigasi, Vol. 17(1), 2016, 3075-3132

DOI: http://dx.doi.org/10.23969/litigasi.v17i1.92

mediator atau arbitrator, dalam kasus yang diteliti berarti pihaknya adalah bank sebagai arranger. Negosiasi dalam aplikasi praktek hukum melibatkan banyak aspek seperti analisa proses kemampuan, tanggung jawab secara profesional, strategi serta mekanisme.

Demikian juga melihat kemungkinan keputusan hasil negosiasi apakah dapat memenuhi kebutuhan para pihak dan bagaimana keputusannya kelak dilaksanakan. Negosiasi dalam praktek hukum adalah berbeda karena melibatkan hubungan mewakili para pihak dan bank. Bank harus membangun hubungan dan pengertian yang terbuka antara nasabah dan mitra usaha dan memiliki tanggung jawab untuk memberikan informasi terbuka selama proses negosiasi berlangsung. Tujuan pihak Bank adalah untuk memberikan hasil terbaik kepada para pihak tetapi bukan merupakan pemenuhan keinginan dari bank sendiri. Bank harus membantu para pihak untuk memantapkan tujuan dan target mereka dalam suatu negosiasi. Para pihak sudah barang tentu telah berdiskusi atau bermusyawarah sedemikian rupa agar kepentingan-kepentingan dan hak-haknya terakomodir menjadi kepentingan atau kebutuhan bersama para pihak yang bersengketa. Pada umumnya kesepakatan bersama tersebut dituangkan secara tertulis.

Mediasi adalah proses negosiasi pemecahan masalah di mana pihak luar yang tidak memihak (impartial) bekerjasama dengan pihak yang bersengketa untuk membantu memperoleh kesepakatan perjanjian dengan memuaskan. Berbeda dengan hakim atau arbiter, mediator tidak mempunyai wewenang

Copyright @ 2016 , LITIGASI, p-ISSN: 0853-7100; e-ISSN: 2442-2274 
Available online at: http://ejournal.unpas.ac.id/index.php/litigasi

Litigasi, Vol. 17(1), 2016, 3075-3132

DOI: http://dx.doi.org/10.23969/litigasi.v17i1.92

untuk memutuskan sengketa. Mediator hanya membantu para pihak untuk menyelesaikan persoalan-persoalan yang dikuasakan kepadanya (Suyud Margono, 2004 : 28).

Menurut Pasal 1 angka 5 Peraturan Bank Indonesia No. 8/5/PBI/2006 tentang Mediasi Perbankan, yang menyatakan Mediasi (Perbankan) adalah proses penyelesaian sengketa yang melibatkan mediator untuk membantu para pihak yang bersengketa guna mencapai penyelesaian dalam bentuk kesepakatan sukarela terhadap sebagian ataupun seluruh permasalahan yang disengketakan.

Dalam sengketa di mana salah satu pihak lebih kuat dan cenderung menunjukkan kekuasaannya, pihak bank syariah memegang peranan penting untuk menyetarakannya. Kesepakatan dapat tercapai dengan mediasi karena pihak yang bersengketa berhasil mencapai saling pengertian dan bersama-sama merumuskan penyelesaian sengketa tanpa arahan konkrit dari pihak bank syariah.

Secara umum mediasi dapat diartikan upaya penyelesaian sengketa para pihak dengan kesepakatan bersama melalui mediator yang bersikap netral, dan tidak membuat keputusan atau kesimpulan bagi para pihak tetapi menunjang fasilitator untuk terlaksananya dialog antar pihak dengan suasana keterbukaan, kejujuran dan tukar pendapat untuk tercapainya mufakat. Dengan kata lain, proses negosiasi pemecahan masalah dimana pihak bank syariah yang tidak memihak (impartial) dan netral bekerja dengan pihak yang bersengketa untuk membantu mereka memperoleh kesepakatan perjanjian dengan memuaskan.

Copyright @ 2016 , LITIGASI, p-ISSN: 0853-7100; e-ISSN: 2442-2274 
Available online at: http://ejournal.unpas.ac.id/index.php/litigasi

Litigasi, Vol. 17(1), 2016, 3075-3132

DOI: http://dx.doi.org/10.23969/litigasi.v17i1.92

Apabila pihak yang bersengketa tidak mampu merumuskan suatu kesepakatan dan pihak bank syariah mengajukan usulan jalan keluar dari sengketa, proses ini disebut konsiliasi. Hal ini yang menyebabkan istilah konsiliasi kadang sering diartikan dengan mediasi. Bagaimanapun juga penyelesaian sengketa model konsiliasi mengacu pada pola proses penyelesaian sengketa secara konsensus antar pihak, di mana pihak netral dapat berperan secara aktif (neutral act) maupun tidak aktif. Pihak-pihak yang bersengketa harus menyatakan persetujuan atas usulan pihak bank syariah tersebut dan menjadikannya sebagai kesepakatan penyelesaian sengketa.

Proses adjudikasi dirangsang untuk memberikan suatu pandangan terhadap sengketa kepada pihak yang bersengketa dibandingkan apabila mereka merancangnya sendiri. Seperti mediasi-arbitrase, persidangan mini, pemeriksaan juri, evaluasi netral secara dini, jadi dilakukannya secara internal para pihak saja.

Dalam persengketaan, perbedaan pendapat dan perdebatan yang berkepanjangan biasanya mengakibatkan kegagalan proses mencapai kesepakatan. Keadaan seperti ini biasanya berakhir dengan putusnya jalur komunikasi yang sehat sehingga masing-masing pihak mencari jalan keluar tanpa memikirkan nasib ataupun kepentingan pihak lainnya.

Agar teciptanya proses penyelesaian sengketa yang efektif, prasyarat yang harus dipenuhi adalah kedua belah pihak harus sama-sama memperhatikan atau menjunjung tinggi hak untuk didengar. Dengan prasyarat tersebut proses dialog dan pencarian titik temu (commond ground) yang akan menjadi

Copyright (C) 2016, LITIGASI, p-ISSN: 0853-7100; e-ISSN: 2442-2274 
Available online at: http://ejournal.unpas.ac.id/index.php/litigasi

Litigasi, Vol. 17(1), 2016, 3075-3132

DOI: http://dx.doi.org/10.23969/litigasi.v17i1.92

panggung proses penyelesaian sengketa baru dapat berjalan. Jika tanpa kesadaran tentang pentingnya langkah ini, proses penyelesaian sengketa tidak berjalan dalam arti yang sebenarnya.

Ada 3 faktor utama yang mempengaruhi proses penyelesaian sengketa, yaitu :

1. Kepentingan (interest),

2. Hak-hak (rights), dan

3. Status kekuasaas (power).

Para pihak yang bersengketa menginginkan agar kepentingannya tercapai, hak-haknya dipenuhi, dan kekuasaannya diperlihatkan, dimanfaatkan, dan dipertahankan. Dalam proses penyelesaian sengketa, pihak-pihak yang bersengketa lazimnya akan bersikeras mempertahankan ketiga faktor tersebut di atas.

Inti dari pembiayaan mudharabah muqaydah merupakan kerjasama, maksudnya adalah upaya bersama untuk mewujudkan suatu tujuan. Fungsinya harus sinergi, bukan keberadaan tetapi saling berkontribusi para pihaknya yang menyebabkan semua harus bertanggung jawab. Para pihak dalam pembiayaan mudharabah muqaydah saling gotong royong untuk mewujudkan tujuan bersama, jadi semua pihak adanya kesederajatan.

Kerjasama dalam perbankan ada dua, kerjasama biasa dan kerjasama syariah. Kerjasama biasa yang pertama, adanya eksploitasi artinya para pihak disini tidak saling gotong royong disebabkan derajat para pihaknya berbeda, ada

Copyright @ 2016, LITIGASI, p-ISSN: 0853-7100; e-ISSN: 2442-2274 
Available online at: http://ejournal.unpas.ac.id/index.php/litigasi

Litigasi, Vol. 17(1), 2016, 3075-3132

DOI: http://dx.doi.org/10.23969/litigasi.v17i1.92

yang lebih tinggi dan ada yang lebih rendah karena saling menekan; kedua, adanya ketergantungan, artinya salah satu pihak yang lebih rendah derajatnya yaitu yang pihak membutuhkan atau nasabah pasti ada faktor ketergantungan untuk mendapatkan apa yang dibutuhkannya. Sedangkan kerjasama syariah, yang pertama, adalah saling gotong royong antar pihak; kedua, para pihak menjadi mitra dalam pembiayaan tersebut; ketiga, berakhirnya kontrak menjadi mitra usaha mandiri.

B. Pelaksanaan tanggung jawab bank syariah terhadap kerugian nasabah penyimpan dana akibat wanprestasi mitra usahanya dalam pembiayaan mudharabah.

Dalam uraian sebelumnya telah dijelaskan bahwa bank dalam pelaksanaan akad mudharabah memiliki peran ganda yaitu sebagai mudharib dalam akad mudharabah yang dilakukan dengan nasabah penyimpan dana, serta bank akan bertindak dalam kedudukannya selaku shahibul maal dalam akad mudharabah yang dilakukan bersama mitra usahanya.

Sebelumnya juga telah diuraikan bahwa mudharabah terbagi 2 yaitu:

1. Mudharabah muthlaqah (Unrestricted investment accout) yaitu mudharabah yang tidak memberi batasan atau persyaratan dalam pelaksanaannya.

2. Mudharabah muqaydah (restricted investment account) yaitu mudharabah yang memberikan batasan atau persyaratan dalam pelaksanaannya pada mudharabah muqaydah ini terbagi lagi jadi 2 jenis:

Copyright @ C 2016, LITIGASI, p-ISSN: 0853-7100; e-ISSN: 2442-2274 
Available online at: http://ejournal.unpas.ac.id/index.php/litigasi

Litigasi, Vol. 17(1), 2016, 3075-3132

DOI: http://dx.doi.org/10.23969/litigasi.v17i1.92

a. Mudharabah muqaydah on balance sheet yaitu aliran dana dari nasabah investor ke sekelompok pelaksana usaha tertentu dengan persyaratan tertentu disebut balance sheet karena dicatatkan dalam neraca bank

b. Mudharabah muqaydah off balance sheet tidak dicatat dalam neraca bank tetapi hanya dalam rekening administratif saja, bank hanya memperoleh arranger fee saja.

Pertanggungjawaban Bank Syariah ada dua, yaitu tanggung jawab normatif dan tanggung jawab moral. Tanggung jawab normatif dari akad mudharabah ini jika diterapkan akan dihasilkan beberapa format akad yang akan berbeda pada bentuk pertanggungjawaban bank atas dana nasabah yaitu sebagai berikut:

1. Ketika nasabah menyimpan dananya dengan akad mudharabah muthlaqah, baik dalam bentuk simpanan tabungan maupun deposito yang menggunakan label mudharabah, dimana pihak bank mempergunakan dana nasabah tersebut untuk mengembangkan usahanya dengan melakukan transaksi dengan pihak lain, dimana transaksi tersebut bisa diprediksi dengan relatif pasti tingkat keuntungan dan jangka waktunya, karena telah diperjanjikan terlebih dahulu di awal akad seperti akad jual beli dan sewa menyewa, atau jenis usaha lain yang dilakukan bank yang bebas riba dan halal, karena dana yang disimpan di bank syariah akan dikelola dan diinvestasikan dengan cara yang anti: Masyir (transaksi bersifat spekulasi, judi), Gharar (Transaksi yang tidak jelas, ), Riba, Batil (perbuatan jahat).

Copyright @ C 2016, LITIGASI, p-ISSN: 0853-7100; e-ISSN: 2442-2274 
Available online at: http://ejournal.unpas.ac.id/index.php/litigasi

Litigasi, Vol. 17(1), 2016, 3075-3132

DOI: http://dx.doi.org/10.23969/litigasi.v17i1.92

Dalam format pelaksanaan mudharabah seperti ini, secara teori jika terjadi kerugian, maka pihak shahibul maal (dalam hal ini nasabah penyimpan dana) akan menanggung seluruh risiko yang menyangkut modal yang dikeluarkan untuk menjalankan usaha bank sepanjang tidak ditemukan bukti penyelewengan dan salah urus dalam pengelolaaan usaha oleh pihak bank selaku mudharib. Nasabah penyimpan tidak perlu takut atas kerugian semacam itu karena kemungkinannya akan sangat kecil sekali mengingat transaksi tersebut bisa diprediksi dengan relatif pasti tingkat keuntungan dan jangka waktunya. Sikap sidiq, tabligh, amanah dan fathonah sebagai penunjang profesionalnya dengan kinerja yang baik menjadi jaminan dari pihak bank kepada nasabah penyimpan untuk menginvestasikan dananya dengan aman dan menguntungkan.

Nasabah penyimpan tidak perlu khawatir akan hilangnya dana simpanan mereka pada bank syariah meskipun menggunakan akad mudharabah dengan regulasi yang ada dana simpanan mereka dijamin pengembaliannya oleh pemerintah melalui lembaga penjamin simpanan sebagaimana termuat dalam Undang-Undang No. 4 tahun 2004 tentang Lembaga Penjamin Simpanan, Lembaga Penjamin Simpanan (LPS) yang diamanatkan dalam Pasal 37B Undang-Undang Republik Indonesia No. 10 tahun 1998 tentang perubahan atas Undang-Undang No. 7 tahun 1992 tentang Perbankan Pasal 37B Undang-Undang Perbankan tersebut secara tegas menuangkan bahwa:

Copyright @ C 2016, LITIGASI, p-ISSN: 0853-7100; e-ISSN: 2442-2274 
Available online at: http://ejournal.unpas.ac.id/index.php/litigasi

Litigasi, Vol. 17(1), 2016, 3075-3132

DOI: http://dx.doi.org/10.23969/litigasi.v17i1.92

"setiap bank wajib menjamin dana masyarakat yang disimpan pada bank yang bersangkutan, dan untuk menjamin simpanan masyarakat pada bank itu"

Pelaksanaan fungsi menjamin simpanan nasabah bank dan turut aktif dalam stabilitas sistem perbankan oleh lembaga penjamin simpanan, yang juga dilaksanakan bagi bank berdasarkan prinsip syariah ini diatur lebih lanjut dengan Peraturan Pemerintah No. 39 Tahun 2005 tentang Penjaminan Simpanan Nasabah Berdasarkan Prinsip Syariah.

Undang-Undang lembaga penjamin simpanan ini memuat, bahwa pada akhirnya pelaksanaan penjamin dana simpanan masyarakat hanya menjamin dana nasabah sebesar Rp. 100.000 .000 (seratus juta rupiah), hal ini tentunya merupakan peluang, dan sekaligus tantangan besar untuk bankbank syariah untuk merangkul nasabah baru yang jadi tertarik dengan peluang investasi sesungguhnya, dengan menerapkan konsep bagi hasil dalam usahanya, yang telah terbukti tidak terpengaruh dengan adanya krisis ekonomi. Perlindungan melalui lembaga penjamin simpanan ini dikenal dengan perlindungan secara eksplisit atau terang-terangan. Selain itu menurut sistem perbankan Indonesia perlindungan terhadap nasabah dapat dilakukan secara implisit.

Emirzon (Emirzon.]., 2001 : 503). merumuskan apa yang dimaksud perlindungan secara implisit adalah perlindungan yang dihasilkan oleh pengawasan dan pembinaan bank yang efektif, yang dapat menghindarkan

Copyright @ C 2016, LITIGASI, p-ISSN: 0853-7100; e-ISSN: 2442-2274 
Available online at: http://ejournal.unpas.ac.id/index.php/litigasi

Litigasi, Vol. 17(1), 2016, 3075-3132

DOI: http://dx.doi.org/10.23969/litigasi.v17i1.92

terjadinya kebangkrutan bank. Cara perlindungan ini dapat diperoleh melalui:

a. Peraturan perundang-undangan di bidang perbankan (Undang-Undang No. 10 Tahun 1998);

b. Perlindungan yang dihasilkan oleh pengawasan dan pembinaan bank yang efektif yang dilakukan oleh Bank Indonesia;

c. Upaya yang menjaga kelangsungan usaha sebagai suatu lembaga pada khususnya dan perlindungan terhadap sistem perbankan pada umumnya;

d. Memelihara tingkat kesehatan bank;

e. Melakukan usaha sesuai dengan prinsip kehati-hatian;

f. Cara pemberian kredit yang tidak merugikan bank dan kepentingan nasabah;

g. Keppres No. 26 Tahun 1998 tentang Jaminan Terhadap Kewajiban Pembayaran Bank Umum.

Selain hal-hal tersebut diatas menambahkan ketentuan lain yang mendukung upaya perlindungan terhadap nasabah, yaitu: dalam memberikan pembiayaan (kredit), bank wajib mempunyai keyakinan atas kemampuan dan kesanggupan calon mitranya, dengan melakukan standar penilaian bank dengan analisis 5C yaitu, Character (watak), Capacity (kemampuan), Capital (permodalan), Condition (kondisi) serta Collateral (tambahan). 
Available online at: http://ejournal.unpas.ac.id/index.php/litigasi

Litigasi, Vol. 17(1), 2016, 3075-3132

DOI: http://dx.doi.org/10.23969/litigasi.v17i1.92

Pada dasarnya berbagai kebijaksanaan di bidang perbankan diterbitkan untuk melindungi semua pihak nasabah, bank serta pemerintah.

2. Ketika nasabah menyimpan dananya dengan akad mudharabah muthlaqah, dan pihak bank mempergunakan dana nasabah tersebut untuk mengembangkan usahanya dengan melakukan transaksi dengan pihak lain menggunakan akad mudharabah sehingga terjadi mudharabah kedua yang dilakukan pihak bank dengan mitra usahanya, dimana transaksi tersebut tidak bisa diprediksi dengan pasti besarnya keuntungan, karena sangat bergantung pada hasil investasi disebabkan yang diperjanjikan terlebih dahulu diawal akad bukanlah besarnya keuntungan melainkan nisbah bagi hasil atau persentase pembagian keuntungan, sedangkan tingkat keuntungan investasinya sendiri bisa positif, nol, atau malah mungkin negatif.

Dalam format pelaksanaan mudharabah seperti ini secara teori jika terjadi kerugian maka pihak bank harus bertanggung jawab penuh atas risiko kerugian atas investasi yang dilakukan nasabah penyimpan dana pada bank tersebut. Tanggung jawab penuh dapat diartikan bahwa bank syariah menjamin pengembalian seluruh dana simpanan nasabah tersebut.

Pada dasarnya konsep mudharabah memang murni investasi untuk usaha atau bisnis, sehingga sangat wajar dalam dunia bisnis tidak selalu mendapatkan keuntungan, dimana ada kalanya akan timbul kerugian yang sudah merupakan karakter bisnis itu sendiri. Secara teori memang bank akan menanggung semua risiko atas kerugian mitra usahanya tersebut sepanjang

Copyright @ 9 2016, LITIGASI, p-ISSN: 0853-7100; e-ISSN: 2442-2274 
Available online at: http://ejournal.unpas.ac.id/index.php/litigasi

Litigasi, Vol. 17(1), 2016, 3075-3132

DOI: http://dx.doi.org/10.23969/litigasi.v17i1.92

tidak ditemukan bukti salah guna dan salah urus dalam pengelolaan usaha oleh mitra usahanya atau sepanjang tidak ditemukan pelanggaran atas syarat-syarat yang ditetapkan pihak bank, namun pihak bank mencoba untuk menghilangkan semua ketidakpastian yang menimbulkan risiko dengan sangat memperketat persyaratan-persyaratan yang harus dipenuhi mitranya, dimana pelanggaran terhadap semua persyaratan dalam akad, akan menjadikan mitra selaku mudharib-nya bertanggung jawab terhadap risiko, sehingga kerugian semacam itu akan sangat jarang sekali terjadi.

Konsep tanggung jawab dimana nasabah penyimpan selaku shahibul maal memberikan kepercayaan untuk pengelolaan sejumlah dana miliknya, kepada pihak bank sebagai haknya selaku mudharib untuk menjalankan bisnisnya sendiri maka akan timbul suatu kewajiban untuk benar-benar bersikap amanah. Sehingga tercipta suatu hubungan hukum yang menimbulkan hak dan kewajiban bagi masing-masing pihak berupa tanggung jawab secara yuridis.

Ketika bank mengalihkan tanggung jawab untuk pengelolaan dana milik nasabah penyimpan dengan menyalurkannya kembali kepada mitra usahanya dengan akad mudharabah, dimana bank dalam kedudukannya akan bertindak selaku shahibul maal dan mitra usahanya selaku mudharib, sudah sepatutnya bank bertanggung jawab penuh atas dana yang seharusnya dipergunakan oleh bank untuk menjalankan usahanya, namun dialihkan untuk menjalankan usaha mitranya, karena nasabah penyimpan

Copyright @ 2016, LITIGASI, p-ISSN: 0853-7100; e-ISSN: 2442-2274 
Available online at: http://ejournal.unpas.ac.id/index.php/litigasi

Litigasi, Vol. 17(1), 2016, 3075-3132

DOI: http://dx.doi.org/10.23969/litigasi.v17i1.92

mempercayakan sejumlah dananya untuk dikelola oleh bank, bukan untuk dikelola oleh mitra bank, sehingga dapat dikatakan bahwa ketika bank melakukan mudharabah kedua dengan mitra usahanya maka, bank telah melampaui batas kewenangan yang diberikan nasabah penyimpannya. Dengan terpenuhinya keempat unsur yaitu Authority, Responsibility, dan Capability serta Accountability sebagai konstruksi tanggung jawab oleh pihak bank maka, bank dapat dimintakan pertanggungjawaban secara yuridis (Sigit. S., $1992: 25-28$ ) atas tindakan atau perbuatan yang dilakukannya yang melampaui batas kewenangan yang diberikan, meskipun kerugian investasi dengan mitra usaha bank akan sangat jarang sekali terjadi.

Disisi lain tanggung jawab bank syariah yang menjadi kewajibannya adalah membagi hasilkan keuntungan yang didapatkan dari hasil usahanya, dengan menggunakan sistem bagi hasil yang berdasarkan revenue sharing dimana bagi hasil yang akan didistribusikan dihitung dari total pendapatan bank sebelum dikurangi dengan biaya-biaya bank, maka kemungkinan yang akan terjadi adalah tingkat bagi hasil yang diterima oleh nasabah penyimpanan (deposan) akan dapat lebih besar dibandingkan dengan tingkat suku bunga pasar yang berlaku. Kondisi ini tentunya akan sangat mempengaruhi pemilik dana untuk mengarahkan investasinya kepada bank syariah yang nyatanya justru memberikan hasil yang optimal, yang pada akhirnya akan berdampak pada peningkatan total dana pihak ketiga pada bank syariah. Hal ini sangat baik sekali dibandingkan jika bank syariah menggunakan sistem profit sharing

Copyright $\odot$ 2016, LITIGASI, p-ISSN: 0853-7100; e-ISSN: 2442-2274 
Available online at: http://ejournal.unpas.ac.id/index.php/litigasi

Litigasi, Vol. 17(1), 2016, 3075-3132

DOI: http://dx.doi.org/10.23969/litigasi.v17i1.92

dimana bagi hasil dihitung dari pendapatan bersih bank setelah dikurangi biaya-biaya, maka kemungkinan yang akan terjadi adalah bagi hasil yang akan diterima nasabah penyimpan dana selaku Shahibul maal akan semakin kecil.

3. Ketika nasabah menyimpan dana meminta pihak bank untuk menyalurkan dananya dengan akad mudharabah muqaydah atau yang dikenal dengan deposito investasi khusus, dimana pemilik dana dapat menetapkan syaratsyarat tertentu yang harus dipatuhi pihak bank, misalnya bahwa dana tersebut hanya boleh digunakan untuk bisnis tertentu, atau hanya untuk nasabah tertentu, ataupun juga dananya dapat digunakan dengan akad tertentu. Pihak bank wajib memberitahukan kepada pemilik dana mengenai nisbah dan tata cara pembagian keuntungan secara risiko yang dapat ditimbulkan dari penyimpan dana. Bentuk investasi dan nisbah pembagian keuntungan biasanya dinegosisasikan secara kasus perkasus (Muhamad, $2005: 52)$

Mudharabah muqaydah seperti ini disebut mudharabah muqaydah on balance sheet karena dana yang dihimpun akan dimasukkan kedalam pembukuan neraca bank yang akan dilaporkan kepada Bank Indonesia. Dana ini akan dipisahkan ke dalam suatu pos dana tersendiri yang disebut dana investasi terkait, dimana dana ini hanya akan dikucurkan apabila pihak bank benar-benar telah mendapatkan mitra usaha yang sesuai dengan kriteria 
Available online at: http://ejournal.unpas.ac.id/index.php/litigasi

Litigasi, Vol. 17(1), 2016, 3075-3132

DOI: http://dx.doi.org/10.23969/litigasi.v17i1.92

yang ditentukan pemilik dana, selain juga telah memenuhi kriteria yang disyaratkan pihak bank.

Dalam format pelaksanaan mudharabah seperti ini, pihak bank bertanggung jawab atas sejumlah dana yang diinvestasikan pemilik dana tersebut, hal ini didasari karena pihak bank diberikan kewenangan oleh si pemilik dana untuk mencarikan mitra usaha yang sesuai dengan kriteria yang ditentukan pemilik dana atas dasar pengetahuan, kemampuan, dan pengalamaan pihak bank dalam memilih mitra usaha yang ideal dan potensial. Selain itu dana mudharabah muqaydah on balance sheet ini juga dijamin pengembaliannya berdasarkan ketentuan Pasal 3 Peraturan Pemerintah No. 39 Tahun 2005 tentang Penjaminan Simpanan Nasabah Bank Berdasarkan Prinsip Syariah.

4. Ketika nasabah pemilik dana meminta pihak bank untuk menyalurkan dananya dengan akad mudharabah muqaydah untuk disalurkan langsung kepada mitra yang telah ditunjuk oleh pemilik dana. Dalam hal pemilik dana meminta bank untuk menyalurkan dana mudharabah secara langsung kepada mitra usaha maka, bank hanya berada pada posisi perantara yang mempertemukan antara pemilik dana dengan mitra usaha yang akan menjalankan usaha. Pihak bank akan mendapatkan komisi atas jasa mempertemukan kedua belah pihak.

Dalam format pelaksanaan mudharabah yang seperti ini secara teori jika terjadi kerugian maka pemilik dana selaku shahibul maal akan menanggung seluruh risiko yang menyangkut modal yang dikeluarkan untuk menjalankan

Copyright @ C 2016, LITIGASI, p-ISSN: 0853-7100; e-ISSN: 2442-2274 
Available online at: http://ejournal.unpas.ac.id/index.php/litigasi

Litigasi, Vol. 17(1), 2016, 3075-3132

DOI: http://dx.doi.org/10.23969/litigasi.v17i1.92

usaha dengan kata lain dapat dikatakan bahwa bank tidak bertanggung jawab atas resiko kerugian investasi yang dilakukan nasabah penyimpan dana dengan mitra usahanya tersebut.

Hasil penelitian yang didapatkan juga menunjukkan bahwa bank syariah di Bandung, terkesan hanya bersedia menerima dana simpanan nasabah dalam bentuk Mudharabah Muthlaqah, dan jika dana tersebut digunakan oleh pihak bank untuk melakukan mudharabah keduanya kepada mitra usahanya, maka tersebut akan disalurkan kembali hanya dengan akad mudharabah muqaydah. Argumentasi yang diberikan pihak bank dengan membatasi bentuk akad mudharabah terhadap nasabah penyimpan maupun nasabah yang hendak menjadi mitranya adalah untuk memperkecil risiko yang akan dihadapi pihak bank.

Pada nasabah penyimpan dana, pihak bank terkesan melakukan pembatasan hanya dengan menggunakan akad mudharabah muthlaqah terhadap dana simpanannya adalah untuk mempermudah pihak bank menjalankan usahanya sehingga pihak bank bebas menentukan sendiri bentuk pengelolaan dana tersebut untuk mendapatkan keuntungan maksimal baik bagi pihak bank sendiri maupun pihak nasabah penyimpan dananya, jika nasabah meminta dananya disimpan dan dipergunakan akad mudharabah muqaydah (deposito investasi), misalnya nasabah tersebut mensyaratkan bahwa dananya hanya boleh dipergunakan untuk pembiayaan usaha perkebunan dengan akad mudharabah, maka pihak bank relatif agak kewalahan untuk

Copyright @ C 2016, LITIGASI, p-ISSN: 0853-7100; e-ISSN: 2442-2274 
Available online at: http://ejournal.unpas.ac.id/index.php/litigasi

Litigasi, Vol. 17(1), 2016, 3075-3132

DOI: http://dx.doi.org/10.23969/litigasi.v17i1.92

mencarikan mitra yang benar-benar memenuhi kriteria ideal dan potensial bagi nasabah penyimpan tersebut, disisi lain terjadi penumpukkan dana untuk disalurkan sehingga tidak memberikan kontribusi maksimal bagi pihak bank dan nasabah penyimpan dana itu sendiri. Namun pembatasan yang dilakukan pihak bank tidaklah mutlak, pada beberapa nasabah tertentu pihak bank bersedia mengelola dana nasabah dengan akad mudharabah muqaydah seperti nasabah atas nama perusahaan $X$ meminta pihak bank mengelola dananya dengan akad mudarabah muqaydah untuk menyalurkan dananya tersebut kepada koperasi $Y$ dimana diketahui bahwa koperasi $Y$ adalah koperasi milik perusahaan $X$ itu sendiri.

Pada proses penyaluran dana mudharabah kepada mitra usahanya pihak bank pasti menyalurkan dana dengan akad mudharabah muqaydah. Ciri khas pembiayaan mudharabah menurut rasa kepercayaan yang sangat tinggi membuat pembiayaan ini menjadi sangat berisiko tinggi, sehingga pihak bank harus benar-benar selektif memilih mitra usahanya untuk menghindari resiko yang sangat tinggi tersebut dengan melakukan pembatasanpembatasan ketika menyalurkan pembiayaan. Batasan yang diberikan pihak bank secara tidak langsung memaksa pihak mitra (mudharib) untuk berprilaku baik dalam usaha memaksimalkan keuntungan bagi keduanya.

Umumnya pihak bank mensyaratkan agar mitra melakukan bisnis yang memiliki risiko operasional yang rendah, harus kas yang transparan dan biaya tak terkontrolnya rendah selain itu pihak bank mensyaratkan agar

Copyright @ C 2016, LITIGASI, p-ISSN: 0853-7100; e-ISSN: 2442-2274 
Available online at: http://ejournal.unpas.ac.id/index.php/litigasi

Litigasi, Vol. 17(1), 2016, 3075-3132

DOI: http://dx.doi.org/10.23969/litigasi.v17i1.92

mitra memberikan jaminan. Jaminan yang diberikan mudharib jauh lebih besar dari nominal modal yang diberikan pihak bank, asumsi pihak bank jika pihak mitra memberikan jaminan yang nominalnya jauh lebih besar maka perilaku mitra untuk berlaku tidak jujur dengan melakukan penyelewengan akan sangat berkurang, karena nilai jaminan yang diberikannya menjadi nilai harga dari penyelewengan perilakunya.

Selain tanggung jawab normatif yang dijelaskan di atas, ada pertanggungjawaban bank syariah yang tidak kalah penting yaitu tanggung jawab moral. Selama ini, definisi bank syariah atau bank Islam adalah bank yang dilandaskan pada nilai-nilai Islam (al-Qur'an, as-sunnah, dan lain-lain). Bank syariah dijabarkan sebagai bank yang beroperasi dengan tidak mengandalkan pada bunga. Dengan kata lain, bank syariah adalah lembaga keuangan yang usaha pokoknya memberikan pembiayaan dan jasa-jasa lainnya dengan prinsip syariat Islam.

Definisi di atas menyiratkan bahwa pengertian bank syariah ternyata berbeda dengan pengertian bank dalam arti konvensional, dimana bank dalam pengertian yang terakhir ini dibatasi sebagai lembaga perantara keuangan atau biasa disebut financial intermediary. Artinya, lembaga bank adalah lembaga yang dalam aktivitasnya berkaitan dengan masalah uang. Oleh karena itu, usaha bank akan selalu dikaitkan dengan masalah uang yang merupakan media transaksi-transaksi ekonomi. Karena itu, kegiatan dan usaha bank konvensional

Copyright @ 2016 , LITIGASI, p-ISSN: 0853-7100; e-ISSN: 2442-2274 
Available online at: http://ejournal.unpas.ac.id/index.php/litigasi

Litigasi, Vol. 17(1), 2016, 3075-3132

DOI: http://dx.doi.org/10.23969/litigasi.v17i1.92

selalu terkait dengan hal-hal yang persoalan ekonomi, yaitu; memindahkan uang, menerima dan membayarkan kembali uang, mendiskonto surat wesel, surat order maupun surat berharga lainnya, membeli dan menjual surat-surat berharga, memberi jaminan bank.

Pengertian bank syariah yang menjadikan sumber-sumber otoritas etika agama Islam (al-Qur’an dan as-Sunnah) sebagai rujukan filosofis dan operasionalnya, membawa konsekuensi bahwa bank syariah memiliki tanggung jawab etis untuk mampu menerjemahkan statemen-statemen moral di dalamnya secara operasional. Hal itulah yang terlihat dari produk-produk bank syariah selama ini mengacu pada berbagai bentuk transasksi fiqh yang diyakini diformulasikan berdasarkan petunjuk al-Qur'an dan praktek Rasulullah SAW. Baik produk yang menggunakan label fiqh seperti mudharabah. murabahah, musyarakah, rahn, salam dan sebagainya, maupun yang sudah dikemas dalam bentuk transaksi kontemporer seperti profit sharing, profit and loss sharing (PLS) dan sebagainya, diupayakan agar selaras dengan aturan-aturan baku dalam fiqh.

Tanggung jawab etis bank syari'ah juga dapat dilihat dari aspek manajemen yang menyertakan keterlibatan Dewan Pengawas Syari'ah (DPS) maupun Dewan Syari'ah Nasional (DSN) sebagai pihak yang ditugasi sekaligus memegang otoritas dalam menentukan legalitas produk yang akan dikeluarkan dari aspek syari’ah.

Copyright @ 2016 , LITIGASI, p-ISSN: 0853-7100; e-ISSN: 2442-2274 
Available online at: http://ejournal.unpas.ac.id/index.php/litigasi

Litigasi, Vol. 17(1), 2016, 3075-3132

DOI: http://dx.doi.org/10.23969/litigasi.v17i1.92

Bank syari’ah di samping memiliki kepentingan bisnis, juga mengusung sebuah tanggung jawab etis yang harus di jalankan, terutama yang terkait dengan fungsi sosialnya.

Perbankan syariah ditujukan untuk mencari keridhaan Allah SWT, untuk memperoleh kebajikan di dunia dan akhirat. Oleh karena itu, setiap kegiatan lembaga keuangan yang dikhawatirkan menyimpang dari tuntunan agama harus dihindari, yaitu dengan cara menjauhkan diri dari unsur riba dan menerapkan sistem bagi hasil dan perdagangan. Dengan mengacu pada al-Qur'an surat alBaqarah ayat 275 dan an- Nisa ayat 29, maka setiap transaksi kelembagaan syariah harus dilandasi atas dasar sistem bagi hasil dan perdagangan atau transaksinya didasari oleh adanya pertukaran antara uang dengan barang. Akibatnya pada kegiatan Muamalat berlaku prinsip ada barang/jasa uang dengan barang, sehingga akan mendorong produksi barang/jasa, mendorong kelancaran arus barang/jasa, dapat dihindari adanya penyalahgunaan kredit, spekulasi, dan inflasi. Prinsip utama bank syariah adalah harus menuju pada pengembangan kesejahteraan masyarakat yang bermuara kepada kondisi sosial masyarakat yang menentramkan. Itulah sebabnya mengapa salah satu misi bank syariah adalah mengutamakan dana dari golongan menengah dan ritel, memperbesar portofolio pembiayaan untuk skala menengah dan kecil, serta mendorong terwujudnya manajemen zakat, infak, dan sedekah yang lebih efektif sebagai cerminan kepada kepedulian sosial.

Copyright @ C 2016, LITIGASI, p-ISSN: 0853-7100; e-ISSN: 2442-2274 
Available online at: http://ejournal.unpas.ac.id/index.php/litigasi

Litigasi, Vol. 17(1), 2016, 3075-3132

DOI: http://dx.doi.org/10.23969/litigasi.v17i1.92

Aspek pelayanan dalam perbankan syariah merupakan gabungan antara aspek moral dan aspek bisnis. Dalam operasionalnya selalu bertujuan untuk mendapatkan keuntungan dan terbebaskan dari unsur perjudian, garar (ketidakjelasan/manipulasi), dan riba. Oleh karena itu, bank syariah tidak bebas bertransaksi semaunya, melainkan harus mengintegrasi nilai-nilai moral dengan tindakan-tindakan ekonomi berdasarkan syariah. Uang dan kekayaan hanya sebatas menjadi alat terpadu untuk mencapai kebaikan dalam masyarakat. Sedangkan landasan utama perbankan syariah adalah keyakinan, kebebasan, kejujuran, dan kegigihan untuk meraih sukses, ditunjang faktor-faktor sumber dana, sumber daya manusia, mitra usaha, dan perkembangan teknologi.

Baik landasan falsafah maupun aspek layanan bank syariah di atas menjadi nilai lebih yang tidak dimiliki oleh bank konvensional. Namun, pada saat yang bersamaan dikhawatirkan hal tersebut juga menjadi kelemahan yang mencolok manakala tidak diimplementasikan dengan sepenuhnya. Kekhawatiran ini bukan tanpa alasan jika melihat pada realitas bank syariah saat ini. Realitas yang dimaksud adalah kondisi-kondisi riil dimana bank syariah; (1) telah mereduksi makna fungsi sosial menjadi peyaluran dana sosial (Zakat, Infak Sadaqah/ ZIS); (2) lebih mementingkan kepentingan jangka pendek dalam bentuk keuntungan materi, tidak ubahnya bank konvensional; (3) lemah dalam aspek sumber daya manusia, dimana SDM yang tersedia kurang atau bahkan tidak mengenal hukum Islam, serta; (4) minimnya upaya sosialisasi atau pendidikan terhadap masyarakat. Hal ini membawa akibat serius terhadap

Copyright $\odot$ 2016, LITIGASI, p-ISSN: 0853-7100; e-ISSN: 2442-2274 
Available online at: http://ejournal.unpas.ac.id/index.php/litigasi

Litigasi, Vol. 17(1), 2016, 3075-3132

DOI: http://dx.doi.org/10.23969/litigasi.v17i1.92

keberlangsungan masa depan bank syari'ah itu sendiri. Faktanya hingga saat ini masyarakat masih awam tentang perbankan syariah, bahkan masyarakat muslim sendiri. Selain itu, selama ini masyarakat yang menjadikan bank syariah sebagai pilihan pada dasarnya hanya didorong oleh ikatan emosional sebagai tuntutan moral seorang muslim dan bukan merupakan pilihan rasional. 
Available online at: http://ejournal.unpas.ac.id/index.php/litigasi

Litigasi, Vol. 17(1), 2016, 3075-3132

DOI: http://dx.doi.org/10.23969/litigasi.v17i1.92

\section{SIMPULAN DAN SARAN}

A. Simpulan

1. Upaya yang dilakukan bank syariah melalui proses yang ditawarkan pembiayaan mudharabah muqaydah yang mempunyai hubungan hukum 3 pihak yaitu shahibul maal (nasabah), bank syariah (perantara), dan mudharib (mitra usaha) mengalami indikasi kerugian tidak sebatas pengawasan tetapi melakukan proses musyawarah mufakat, dan juga melaksanakan Alternative Dispute Resolution (ADR) yang dilakukan para pihak termasuk bank syariah sebagai perantara untuk mencapai tujuan kerjasama dalam hal penyelamatan dana shahibul maal dan kegiatan usaha mudharib.

2. Pertanggungjawaban bank syariah ada dua, yaitu tanggung jawab normatif dan tanggung jawab moral. Tanggung jawab normatif artinya yang seharusnya dilaksanakan para pihak menurut format kesepakatan dalam pembiayaan, meskipun setiap format pembiayaan berbeda-beda pertanggungjawabannya. Dalam hal pembiayaan mudharabah muqaydah yang dilakukan penelitian, bank bertanggung jawab sebatas kewajiban pelaksanaan manajemen mitra usaha. Bank syariah tidak bebas bertransaksi semaunya, melainkan harus mengintegrasi nilai-nilai moral dengan tindakan-tindakan ekonomi berdasarkan syariah. Sedangkan landasan utama perbankan syariah adalah keyakinan, kebebasan, kejujuran, dan kegigihan untuk meraih sukses, ditunjang faktor-faktor sumber dana, sumber daya manusia, mitra usaha, dan perkembangan teknologi.

Copyright @ 2016 , LITIGASI, p-ISSN: 0853-7100; e-ISSN: 2442-2274 
Available online at: http://ejournal.unpas.ac.id/index.php/litigasi

Litigasi, Vol. 17(1), 2016, 3075-3132

DOI: http://dx.doi.org/10.23969/litigasi.v17i1.92

B. Saran

1. Dalam perspektif ke depan, untuk pelaksanaan pembiayaan mudharabah hendaknya antara bank sebagai shahibul maal dan mudharib selain dilakukan analisis kelayakan yang cermat terhadap usaha mudharib, maka perlu dilakukan kerjasama yang lebih baik, sehingga kemungkinan terjadinya cidera janji atau wanprestasi oleh mudharib tidak terjadi. Pembiayaan mudharabah muqaydah mempunyai tujuan untuk mencapai kerjasama syariah. Maka bank syariah harus di desain betul dalam melakukan segala pembiayaan, tidak sekedar menyalurkan dana dari berbagai pihak.

2. Bank Syariah harus merubah paradigma bisnis, dimana tujuan bisnis perbankan syariah tidak semata-mata untuk mengejar profil semata, tetapi juga tetap memperhatikan legalitas (dalam perspektif Islam) terhadap produkproduknya. Bank Syariah juga melakukan Social education dalam bentuk penyadaran kepada masyarakat bahwa kelebihan perbankan syari'ah tidak hanya diwujudkan dalam minimnya risiko loose yang ditanggung (karena tidak terikat langsung dengan fluktuasi tingkat suku bunga), tetapi juga diwujudkan dalam bentuk pencapaian keuntungan sosial (karena dilandaskan pada standar-standar moral semisal kepercayaan, keadilan, kejujuran dan sebagainya).

Copyright @ 9 2016, LITIGASI, p-ISSN: 0853-7100; e-ISSN: 2442-2274 


\section{DAFTAR PUSTAKA}

\section{BUKU}

Adiwarman A. Karim, 2006, Bank Islam Analisis Fiqih dan Keuangan, Cetakan ke-3, Jakarta: Rajawali Press.

Anshori. Abdul Ghofur, 2008, Kapita Selekta Perbankan Syariah Di Indonesia, Yogyakarta: UII Press.

Emirzon J., 2001, Hukum perbankan Indonesia, Kelompok Studi Hukum dan Bisnis Fakultas Hukum UNSRI.

Muhammad, 2001, Sistem dan Prosedur Operasional Bank Syariah. Yogyakarta: UII Press.

Muhamad, 2005, Konstruksi Mudharabah Dalam Bisnis Syariah, Mudharabah Dalam Wacana Fiqh dan Praktik Ekonomi Modern, Yogyakarta: BPFE.

Muhammad Syafi'i Antonio, 2001, Bank Syariah Dari Teori Ke Praktek, Jakarta: Gema Insani Press.

Sigit. S, 1992, Pengorganisasian, Fakultas Ekonomi, Yogyakarta: Universitas Gajah Mada.

Susanti Adi Nugroho, 2009, Mediasi Sebagai Alternatif Penyelesaian Sengketa, Jakarta: PT. Telaga IImu Indonesia.

Suyud Margono, 2004, ADR dan Arbitrase (Proses Pelembagaan dan Aspek Hukum), Bogor: Ghalia Indonesia.

\section{PERATURAN PERUNDANGAN}

Undang-Undang Dasar Negara Republik Indonesia Tahun 1945 Amandemen ke-4.

Undang-Undang No. 7 Tahun 1992 tentang Perbankan.

Undang-Undang No. 10 Tahun 1998 tentang Perubahan atas Undang-Undang No. 7 Tahun 1992 tentang Perbankan.

Undang-Undang No. 3 Tahun 2004 tentang perubahan atas Undang-Undang No. 23 Tahun 1999 tentang Bank Indonesia. 
Undang-Undang No. 17 Tahun 2007 Tentang tentang Rencana Pembangunan Jangka Panjang Nasional Tahun 2005-2025.

Undang-Undang No. 21 Tahun 2008 tentang Perbankan Syariah.

PBI No.7/46/PBI/2005 tentang Akad Penghimpunan Dan Penyaluran Dana Bagi Bank Yang Melaksanakan Kegiatan Usaha Berdasarkan Prinsip Syariah.

PBI No. 10/16/PBI/2008 tentang Perubahan Atas Peraturan Bank Indonesia No. 9/19/PBI/2007 tentang Pelaksanaan Prinsip Syariah Dalam Kegiatan Penghimpunan Dana Dan Penyaluran Dana Serta Pelayanan Jasa Bank Syariah.

Surat Edaran Bank Indonesia No. 10/14/DPbS/Jakarta/17 Maret 2008 tentang Pelakanaan Prinsip Syariah Dalam Kegiatan Penghimpunan Dana Dan Penyaluran Dana Serta Pelayanan Jasa Bank Syariah. 